\title{
Addition of $\mathrm{CeO}_{2}$ Nanorods in PtSn-Based Electrocatalysts for Ethanol Electrochemical Oxidation in Acid Medium
}

\author{
Tuani C. Gentil, ${ }^{a}$ Victor S. Pinheiro, ${ }^{a}$ Edson C. Paz, ${ }^{a}$ Felipe M. Souza, ${ }^{a}$ \\ Luanna S. Parreira ${ }^{b}$ and Mauro C. Santos ${ }^{\oplus *, a}$
}

\author{
${ }^{a}$ Laboratório de Eletroquímica e Materiais Nanoestruturados, Centro de Ciências Naturais e Humanas (CCNH), \\ Universidade Federal do ABC (UFABC), 09210-170 Santo André-SP, Brazil \\ ${ }^{b}$ Instituto de Química, Universidade de São Paulo, Av. Prof. Lineu Prestes, 748, \\ 05508-000 São Paulo-SP, Brazil
}

\begin{abstract}
This work describes the preparation of $\mathrm{Pt} / \mathrm{C}, \mathrm{Pt}_{\mathrm{x}} \mathrm{Sn}_{\mathrm{y}} / \mathrm{C}$ and $\mathrm{Pt}_{\mathrm{x}} \mathrm{Sn}_{\mathrm{y}}\left(\mathrm{CeO}_{2}\right.$ nanorods/C) nanoparticle catalysts synthesized by the chemical reduction method via sodium borohydride for the ethanol oxidation reaction. Using X-ray diffractogram analysis, it was verified that no alloy formation occurred between platinum $(\mathrm{Pt})$ and tin $(\mathrm{Sn})$. The distribution of the nanoparticles in the support occurs in a more agglomerated form for the materials containing $\mathrm{Sn}$ and $\mathrm{CeO}_{2}$ nanorods (NR). The electrocatalyst $\mathrm{Pt}_{3} \mathrm{Sn}_{1} 20 \% \mathrm{NRCeO}_{2} / \mathrm{C}$ was highlighted in $\mathrm{CO}$-stripping experiments because it showed the lowest onset potential for $\mathrm{CO}$ oxidation and the highest value for the electrochemically active surface area. The other electrochemical experiments for ethanol oxidation showed similar activities for the $\mathrm{Pt}_{3} \mathrm{Sn}_{1} / \mathrm{C}$ and $\mathrm{Pt}_{3} \mathrm{Sn}_{1} 20 \% \mathrm{NRCeO}_{2} / \mathrm{C}$ electrocatalysts. The observed effect can be associated with defects in the structure of the $\mathrm{CeO}_{2}$ nanorods, the electrochemical active surface area, and the properties of the $\mathrm{CeO}_{2}$ nanorods related to enhancing the generation of oxy-hydroxy species at lower potentials compared to $\mathrm{PtSn} / \mathrm{C}$ electrocatalysts, which increased the CO oxidation as measured using stripping experiments. For this reason, it is possible to both use less platinum and to obtain behavior close to that of $\mathrm{PtSn} / \mathrm{C}$ electrocatalysts for ethanol oxidation reaction (EOR).
\end{abstract}

Keywords: electrocatalysis, ethanol, fuel cells, platinum-tin, ceria nanorods

\section{Introduction}

The main energy matrix used today continues to be oil, but it is a nonrenewable energy source that results in the high emission of polluting gases. For this reason, new matrices are sought for the purpose of supplying the demand for energy that is inevitably necessary. ${ }^{1}$ Consequently, fuel cells stand out, as they have the potential to supply energy in a way that is less aggressive to health and the environment, with significant yields when compared to combustion engines. ${ }^{1,2}$

The most common type of fuel cells are of the PEMFC type (protons exchanging membranes fuel cells). These cells can oxidize fuels such as hydrogen, or small organic molecules such as methanol and ethanol, and can operate in acid or alkaline media. ${ }^{3,4}$ The particularity of PEMFC is the presence of a polymeric electrolyte that allows the passage of protons from the anode to the cathode. This electrolyte

*e-mail: mauro.santos@ufabc.edu.br is a polymer with a main chain of polytetrafluoroethylene (PTFE) that is capable of promoting chemical stability with high proton driving capacity in addition to optimal mechanical resistance. ${ }^{3,5,6}$

In DEFCs (direct ethanol fuel cells) it is possible to obtain an energy density of $8.00 \mathrm{~kW} \mathrm{~kg}^{-1}$, starting from the principle of the transfer of 12 electrons for each oxidized molecule; however, some characteristics of the ethanol molecule make the oxidation process difficult since there is a need for the cleavage of carbon bonding or for oxidation to $\mathrm{CO}_{2}$ and water. ${ }^{7}$

Platinum has high activity as an electrocatalyst in the ethanol oxidation processes in DEFCs, but some challenges such as catalytic poisoning caused by carbon monoxide (CO) due to the oxidation of the fuel are still evident. It is well-known that the synergistic effects of the application of platinum and tin as electrocatalysts on direct ethanol fuel cell anodes is most pronounced for this kind of reaction. ${ }^{8}$

The electronic effect boils down to the interaction of the secondary metal $(\mathrm{Sn})$ with the effective metal $(\mathrm{Pt})$, 
resulting in the alteration of the energy levels for the $5 \mathrm{dPt}$ band and a weaker interaction between compounds such as carbon monoxide $(\mathrm{CO})$ and the effective metal $(\mathrm{Pt}){ }^{9,10}$ $\mathrm{CO}$ is responsible for promoting catalytic poisoning, ${ }^{11,12}$ a situation in which it occupies the active sites for $\mathrm{Pt}$ hindering interactions with organic molecules of interest, and forms with significant quantity via known synthesis, routes for ethanol oxidation processes. ${ }^{10,13,14}$ For this reason, it is important to understand such mechanisms and to develop catalysts capable of diminishing their formation during the processes of electrocatalysis. ${ }^{3}$

The electronic effect of Pt-Sn type electrocatalysts is not only due to the unique contribution of $\mathrm{Sn}$, but also due to the bifunctional mechanism. ${ }^{13,15,16} \mathrm{SnO}_{2}$ provides oxygenated species, facilitating the oxidation of intermediate compounds formed by the incomplete oxidation of the fuel, releasing the platinum sites. ${ }^{8,9,17}$

In conjunction with the tin, the application of cerium oxide $\left(\mathrm{CeO}_{2}\right)$ has been studied since both have a synergistic interaction capable of improving the oxidation of intermediate compounds in addition to allowing the reduction of costs arising from the use of noble metals such as Pt. ${ }^{18-21}$

Neto et al. ${ }^{22}$ carried out the synthesis of $\mathrm{PtSn} / \mathrm{CeO}_{2}-\mathrm{C}$ type electrocatalysts for ethanol electrooxidation, evaluating an increase in activity for materials containing $15 \%$ by mass of $\mathrm{CeO}_{2}$ in their constitution when compared to electrocatalysts composed of only $\mathrm{PtSn} / \mathrm{C}$.

The exploration of different structures in the constitution of the electrocatalysts, such as cerium oxide nanorods (NR), was approached in this work since $\mathrm{CeO}_{2}$ presents a fluorite cubic structure, characterized by the stability of the conformation, allowing oxygen mobility in its crystalline network. These structures were used in conjunction with platinum and tin and supported by carbon, highlighting the environmental bias by proposing a reduction in the use of high-cost metals by replacing part of the metallic charge with $\mathrm{CeO}_{2}$ nanorods in addition to the use of green fuels, such as ethanol. , $^{3,23-25}$

Therefore, the aim of this work is to explore differentiated structures of $\mathrm{CeO}_{2}$ nanorods in PtSn/C based on electrocatalysts prepared by the chemical reduction method via sodium borohydride for the electrocatalytic oxidation of ethanol in acidic medium. ${ }^{26}$ In addition, we study their respective activities when prepared in different mass proportions, effecting replacement of part of the high cost metallic load by $\mathrm{CeO}_{2}$ nanorods. $\mathrm{Pt} / \mathrm{C}$, $\mathrm{Pt}_{1} \mathrm{Sn}_{1} / \mathrm{C}, \mathrm{Pt}_{2} \mathrm{Sn}_{1} / \mathrm{C}, \mathrm{Pt}_{3} \mathrm{Sn}_{1} / \mathrm{C}, \mathrm{Pt}_{3} \mathrm{Sn}_{1-} 5 \% \mathrm{NRCeO}_{2} / \mathrm{C}$, $\mathrm{Pt}_{3} \mathrm{Sn}_{1-} 10 \% \mathrm{NRCeO}_{2} / \mathrm{C}$ and $\mathrm{Pt}_{3} \mathrm{Sn}_{1} 20 \% \mathrm{NRCeO}_{2} / \mathrm{C}$ were synthesized with $20 \%$ by mass of metallic filler and $80 \%$ by mass of the carbon carrier, with the purpose of improving the activity of the electrocatalyst to ethanol oxidation reaction (EOR) and reduce amount of high cost metals by the use of secondary metals $(\mathrm{Sn})$ and $\mathrm{CeO}_{2}$ nanorods. These electrocatalysts were characterized by $\mathrm{X}$-ray diffraction (XRD), transmission electron microscopy (TEM), scanning electron microscopy (SEM) and energy dispersive spectroscopy (EDS) techniques. The activities of the electrocatalysts for ethanol oxidation were evaluated through cyclic voltammetry, chronoamperometry and CO-stripping measurements.

\section{Experimental}

\section{Preparation of the electrocatalysts}

The synthesis of nanoparticulate electrocatalysts was performed using the chemical reduction method via sodium borohydride. ${ }^{26-28}$ Such synthesis involves the dissolution of tin chloride $\left(\mathrm{SnCl}_{2}\right.$, Sigma-Aldrich) in water and the addition of sodium citrate $(1: 1$ in mass ratio with the metallic charge) $\left(\mathrm{Na}_{3} \mathrm{C}_{6} \mathrm{H}_{5} \mathrm{O}_{7}\right.$, Sigma-Aldrich), which has a stabilizing action, to avoid the agglomeration of the nanoparticles, and the subsequent addition of the reducing agent sodium borohydride $0.01 \mathrm{~mol} \mathrm{~L}^{-1}$ (approximately $10 \mathrm{~mL})\left(\mathrm{NaBH}_{4}\right.$, Sigma-Aldrich). ${ }^{11,26-29}$

Approximately $10 \mathrm{~mL}$ of potassium hydroxide $0.01 \mathrm{~mol} \mathrm{~L}^{-1}$ (KOH, Synth) ${ }^{29}$ was added to maintain the alkaline medium and to avoid degradation of the reducing agent, which occurs in neutral and acidic media. ${ }^{11,26-28}$ Heating was performed at $90^{\circ} \mathrm{C}$ on a hot plate with stirring for approximately $30 \mathrm{~min}$. Then, the hexachloroplatinic acid $\left(\mathrm{PtCl}_{6} \mathrm{H}_{2}\right.$, Sigma-Aldrich) is added and the mixture was heated and stirred at the same temperature for a further $30 \mathrm{~min}$. A Vulcan XC-72 (Cabot) carbon dispersion was prepared and added to the above mixture, which was then heated for an additional 30 min under the same conditions. Drying was carried out in an oven at $70{ }^{\circ} \mathrm{C}$ for approximately 24 h. ${ }^{11,26,29}$

The above procedure follows the same criteria used for materials that contain nanorods; however, these were added before the addition of the Vulcan XC-72 carbon in the form of dispersions to facilitate the homogeneity of the electrocatalyst. $^{23,25,30}$

The synthesized electrocatalysts were $\mathrm{Pt} / \mathrm{C}$, $\mathrm{Pt}_{3} \mathrm{Sn}_{1} / \mathrm{C}, \mathrm{Pt}_{2} \mathrm{Sn}_{1} / \mathrm{C}, \mathrm{Pt}_{1} \mathrm{Sn}_{1} / \mathrm{C}, \mathrm{Pt}_{3} \mathrm{Sn}_{1-} 5 \% \mathrm{NRCeO}_{2} / \mathrm{C}$, $\mathrm{Pt}_{3} \mathrm{Sn}_{1-} 10 \% \mathrm{NRCeO}_{2} / \mathrm{C}$ and $\mathrm{Pt}_{3} \mathrm{Sn}_{1-} 20 \% \mathrm{NRCeO}_{2} / \mathrm{C}$ and were composed of $20 \%$ by mass of metal and $80 \%$ by mass of carrier (Vulcan Carbon XC-72). The proportions used for the mass ratio between base metal and secondary metal were 3:1 (75\% Pt:25\% Sn); 2:1 (67\% Pt:33\% Sn); and 1:1 (50\% Pt:50\% Sn). The metal charge composes 
$20 \%$ of the total mass of the electrocatalyst, and $80 \%$ of the mass of the electrocatalyst is composed of Vulcan XC-72 (Cabot) carbon. For materials containing nanorods, 5,10 and $20 \%$ of the metallic charge was replaced by $\mathrm{CeO}_{2}$ nanorods, obtaining electrocatalysts of type $\mathrm{Pt}_{3} \mathrm{Sn}_{1-} \% \mathrm{NRCeO}_{2} / \mathrm{C}$, maintaining $80 \%$ of the mass of the electrocatalyst composed by Vulcan XC-72 (Cabot) carbon and substituting part of the metal filler with $\mathrm{CeO}_{2}$ nanorods, yielding the following materials: $\mathrm{Pt}_{3} \mathrm{Sn}_{1-} 5 \% \mathrm{NRCeO}_{2} / \mathrm{C}$, $\mathrm{Pt}_{3} \mathrm{Sn}_{1-} 10 \% \mathrm{NRCeO}_{2} / \mathrm{C}$ and $\mathrm{Pt}_{3} \mathrm{Sn}_{1} \_20 \% \mathrm{NRCeO}_{2} / \mathrm{C}$.

The synthesis of the nanorods was performed using the hydrothermal method, according to studies..$^{18,20,31,32}$ In this synthesis, cerium nitrate(III) hexahydrate $\left(\mathrm{Ce}\left(\mathrm{NO}_{3}\right)_{3} \cdot 6 \mathrm{H}_{2} \mathrm{O}\right)$ was used as a metallic precursor and sodium hydroxide as an oxidizing agent in a ratio of 1:5. Thus, $4.125 \mathrm{~g}$ of $\mathrm{Ce}\left(\mathrm{NO}_{3}\right)_{3} \cdot 6 \mathrm{H}_{2} \mathrm{O}$ and $19.2 \mathrm{~g}$ of $\mathrm{NaOH}$ were dissolved in $40 \mathrm{~mL}$ of deionized water, with constant stirring for $30 \mathrm{~min}$. Both reagents were transferred to a beaker until dissolution and then transferred to a $50 \mathrm{~mL}$ stainless-steel vessel with an internal polytetrafluoroethylene (PTFE) coating. ${ }^{20}$ The mixture was heated to $100^{\circ} \mathrm{C}$ for $24 \mathrm{~h}$ and then centrifuged, after which the sediment was washed with distilled water and ethanol. The sediment was transferred to a porcelain bottle and dried at $80^{\circ} \mathrm{C}$ for $10 \mathrm{~h}$. After drying, the material was calcined at $500^{\circ} \mathrm{C}$ for $3 \mathrm{~h}$ in a muffle..$^{18,20,33}$

\section{Physical characterization}

The physical characterization of the electrocatalysts was carried out using X-ray diffraction (XRD) with a D8 Focus diffractometer (Bruker AXS with $\mathrm{Cu} \mathrm{K} \alpha$ radiation source) and a continuous scan of $2^{\circ} \min ^{-1} ;^{3}$ $\mathrm{X}$-ray dispersive energy spectroscopy (EDS $)^{3,4}$ using an SEM JEOL JSM-6010LA; scanning electron microscopy $(\mathrm{SEM}){ }^{3,4}$ using a FESEM JEOL JSM-7401F and electronic transmission electron microscopy (TEM) using a JEOL JEM 2100 microscope operating at $200 \mathrm{kV}{ }^{3}$

\section{Electrochemical characterization and activities of the nanoparticle electrocatalysts}

The electrocatalysts were electrochemically characterized by cyclic voltammetry and the same technique was used to evaluate their respective activities for the oxidation reaction of ethanol in acid medium using additional chronoamperometric measurements..$^{34,35}$ An electrochemical cell was used containing $0.5 \mathrm{~mol} \mathrm{~L}^{-1}$ sulfuric acid $\left(\right.$ at $25^{\circ} \mathrm{C}$ ), a reversible hydrogen electrode (RHE) as reference electrode and a Pt wire as a counter electrode. ${ }^{2,9,26}$

The electrocatalytic activity of the materials was studied by cyclic voltammetry for the ethanol oxidation reaction of $1.0 \mathrm{~mol} \mathrm{~L}^{-1}\left(\mathrm{C}_{2} \mathrm{H}_{6} \mathrm{O}\right.$, Synth) in the presence of nitrogen $\left(\mathrm{N}_{2}\right.$, White Martins) under the same conditions mentioned for the electrochemical characterization stage., ${ }^{926,27}$ For chronoamperometric measurements, the same electrochemical cell conditions for cyclic voltammetry were used with fixed potentials of $0.3,0.4$ and $0.5 \mathrm{~V}$ for a period of 1800 s. ${ }^{9,26}$

The activity of the electrocatalysts for carbon monoxide (CO) oxidation was evaluated using $0.5 \mathrm{~mol} \mathrm{~L}^{-1}$ sulfuric acid as electrolyte. The procedure involves the adsorption of $\mathrm{CO}$ at $20 \mathrm{mV}$ for $15 \mathrm{~min}$ under agitation, ensuring the formation of a saturated $\mathrm{CO}$ layer, and subsequent removal of $\mathrm{CO}$ with the aid of bubbling $\mathrm{N}_{2}$ for approximately 30 min. ${ }^{26}$ The experiments were performed in the middle of $\mathrm{H}_{2} \mathrm{SO}_{4} 0.5 \mathrm{~mol} \mathrm{~L}^{-1}$ vs. RHE for obtaining the cyclic voltammograms. A monolayer of $\mathrm{CO}$ was formed on the surface of the working electrode following the bubbling of carbon monoxide with a pressure of 2 bar for a period of $5 \mathrm{~min}$. The electrocatalyst was submitted to three consecutive voltammetric cycles with a sweep rate of $10 \mathrm{mV} \mathrm{s}^{-1}$ in the potential range of $0.05-1.0 \mathrm{~V}$ versus RHE. The voltammograms were compared before and after the CO oxidation. ${ }^{11}$

Electrochemical analyzes were performed with an Autolab PGSTAT 302N potentiostat/galvanostat.

\section{Results and Discussion}

Figure 1 shows the XRD for $\mathrm{Pt}_{3} \mathrm{Sn}_{1} / \mathrm{C}, \mathrm{Pt}_{2} \mathrm{Sn}_{1} / \mathrm{C}$, $\mathrm{Pt}_{1} \mathrm{Sn}_{1} / \mathrm{C}$ and $\mathrm{Pt} / \mathrm{C}$ in which the platinum crystallographic peak patterns are evident in $2 \theta: 39^{\circ}(111) ; 46^{\circ}(200)$ and $68^{\circ}$ (220), respectively. ${ }^{8,14,36,37}$ These peaks do not show shifts in their values for $2 \theta$ removed in the materials $\mathrm{PtSn} / \mathrm{C}$, identifying the nonformation of alloy between the two metals, which would imply a shift in the diffraction angle for smaller values and changes in the lattice parameter. ${ }^{26,27}$

The XRD analyzes were used to determine the network parameter based on the principles of Bragg's law in which the interplanar distance is determined, ${ }^{4,38}$ as shown in equation 1 , and were subsequently applied in the lattice parameter formula.

$\mathrm{d}=\frac{\mathrm{n} \lambda}{2 \operatorname{sen} \theta}$

The interplanar distance represented by the letter $\mathrm{d}$ is calculated using the following elements: the diffraction order (n), evaluated to be 1 for cubic structures that are centered face cubic ( $\mathrm{cfc}$ ), as is the case of platinum; the wavelength of the electromagnetic radiation in nanometers, 
represented by the letter $\lambda$ and evaluated to be $1.54056 \AA$; and the sine of the diffraction angle $\theta$ in degrees. ${ }^{4,38}$

The value $d$ is applied in equation 2 below for determining the lattice parameters:

$\frac{1}{\mathrm{~d}^{2}}=\frac{h^{2}+k^{2}+l^{2}}{a^{2}}$

The letters $h ; k$ and $l$ are the Miller indices according to the peak analyzed; the lattice parameter is determined by the resultant represented by the letter $a .^{4,38}$

Crystallographic planes for $\mathrm{SnO}_{2}$ were observed at $26^{\circ}(110)$ and for $\mathrm{NaCl}$ at (220) and (311) since the borohydride sodium reducing agent is present in the synthesis. The washing of the electrocatalyst during the synthesis was carried out with reduced amounts of solvents aiming at the decrease in the production of residues resulting from the wash water. For this reason, the entire $\mathrm{NaCl}$ was not removed, as verified in the XRD diffractograms.

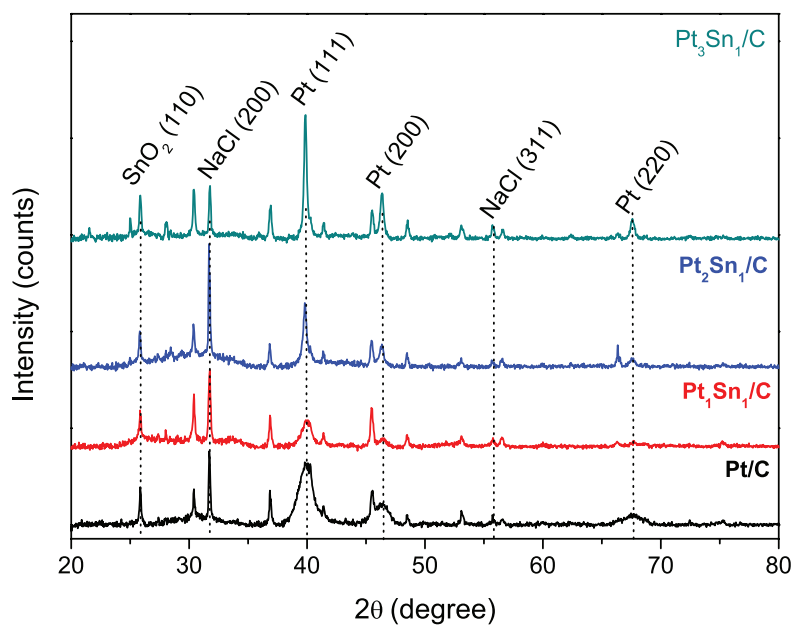

Figure 1. XRD patterns for the $\mathrm{Pt}_{3} \mathrm{Sn}_{1} / \mathrm{C}, \mathrm{Pt}_{2} \mathrm{Sn}_{1} / \mathrm{C}, \mathrm{Pt}_{1} \mathrm{Sn}_{1} / \mathrm{C}$ and $\mathrm{Pt} / \mathrm{C}$ electrocatalysts prepared using the chemical reduction method via sodium borohydride.

The diffractograms in Figure 2 refer to the materials $\mathrm{Pt}_{3} \mathrm{Sn}_{1-} 20 \% \mathrm{NRCeO}_{2} / \mathrm{C}, \mathrm{Pt}_{3} \mathrm{Sn}_{1-} 10 \% \mathrm{NRCeO}_{2} / \mathrm{C}$ and $\mathrm{Pt}_{3} \mathrm{Sn}_{1} 5 \% \mathrm{NRCeO}_{2} / \mathrm{C}$, in which the presence of $\mathrm{NR}$, identified by the peaks at $26^{\circ}(111)$ and $30^{\circ}(200)$, was verified in addition to the characteristic peak for $\mathrm{SnO}_{2}$ at $26^{\circ}$ (110). There was also no alloy formation due to the nonshifting of the platinum peaks identified in the X-ray diffraction analysis.

With the results from Figures 1 and 2, Table 1 was built, in which the lattice parameter values obtained were described.

The lattice parameters for $2 \theta=39,46$ and $68^{\circ}$ remained close to the values found in the literature ${ }^{9,10}$ for situations

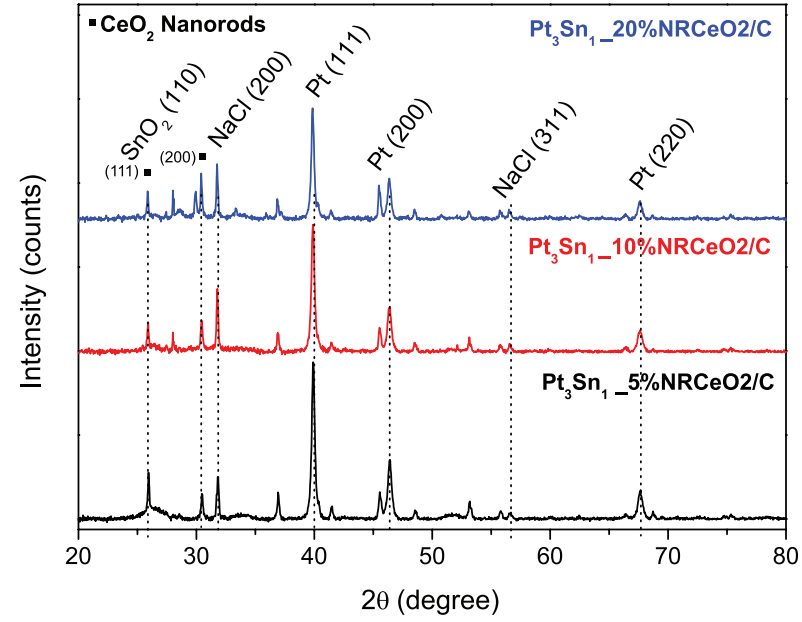

Figure 2. X-ray diffraction patterns for the $\mathrm{Pt}_{3} \mathrm{Sn}_{1-} 5 \% \mathrm{NRCeO}_{2} / \mathrm{C}$, $\mathrm{Pt}_{3} \mathrm{Sn}_{1-} 10 \% \mathrm{NRCeO}_{2} / \mathrm{C}, \mathrm{Pt} 3 \mathrm{Sn}_{1} \_20 \% \mathrm{NRCeO}_{2} / \mathrm{C}$ and $\mathrm{Pt} / \mathrm{C}$ electrocatalysts prepared using the chemical reduction method via sodium borohydride.

Table 1. Lattice parameters for the nanoparticle electrocatalysts determined from the Pt (111), Pt (200) and Pt (220) peaks

\begin{tabular}{lccc}
\hline Electrocatalyst & $\begin{array}{c}\text { Lattice } \\
\text { parameter } \\
39^{\circ} / \mathrm{nm}\end{array}$ & $\begin{array}{c}\text { Lattice } \\
\text { parameter } \\
46^{\circ} / \mathrm{nm}\end{array}$ & $\begin{array}{c}\text { Lattice } \\
\text { parameter } \\
68^{\circ} / \mathrm{nm}\end{array}$ \\
\hline $\mathrm{Pt} / \mathrm{C}$ & 0.3912 & 0.3914 & 0.3917 \\
$\mathrm{Pt}_{1} \mathrm{Sn}_{1} / \mathrm{C}$ & 0.3905 & 0.3909 & 0.3984 \\
$\mathrm{Pt}_{2} \mathrm{Sn}_{1} / \mathrm{C}$ & 0.3919 & 0.3915 & 0.3917 \\
$\mathrm{Pt}_{3} \mathrm{Sn}_{1} / \mathrm{C}$ & 0.3914 & 0.3913 & 0.3917 \\
$\mathrm{Pt}_{3} \mathrm{Sn}_{1-} 5 \% \mathrm{NRCeO}_{2} / \mathrm{C}$ & 0.3908 & 0.3911 & 0.3916 \\
$\mathrm{Pt}_{3} \mathrm{Sn}_{1-10 \% \mathrm{NRCeO}_{2} / \mathrm{C}}$ & 0.3912 & 0.3913 & 0.3916 \\
$\mathrm{Pt}_{3} \mathrm{Sn}_{1-} 20 \% \mathrm{NRCeO}_{2} / \mathrm{C}$ & 0.3915 & 0.3914 & 0.3916 \\
\hline
\end{tabular}

where there is no alloy formation; therefore, there is no peak shift and no modification of the lattice parameter for the platinum.

Parreira et al..$^{7}$ synthesized electrocatalysts containing PtSn alloys and found that there are more sites available for oxyhydroxide species due to the presence of tin, providing a greater number of electrons for EOR when compared to electrocatalyst without $\mathrm{Sn}$, fact evidenced by chronoamperometry performed in the studies.

Parreira et al. ${ }^{7}$ showed that the addition of $\mathrm{Sn}$ in platinum-based electrocatalysts can promote the displacement of $2 \theta$ to lower values, resulting in the expansion of the platinum crystal lattice due to the increase in the lattice parameter. PtSn alloys as well as tin oxides favor the oxidation of adsorbed CO. In addition, changes in the structure of the electrocatalyst can occur due to the removal of hydroxyl species, making the electrocatalyst behave as pure platinum, allowing the oxidation of ethanol and the formation of acetaldehyde at low potentials. 
According to Kuznetsov et al.,$^{39}$ the incorporation of $\mathrm{Sn}$ into the face centered cubic (fcc) structure of Pt resulted in the formation of alloys between both metals, shifting $2 \theta$ to smaller values; however, in addition to the presence of $\mathrm{SnO}_{2}$ peaks, no alloys were obtained between $\mathrm{Pt}$ and $\mathrm{Sn}$ in the synthesized electrocatalysts.

The XRD plots were used to estimate the average crystallite sizes by means of the cutoff considering the width at half height for the plateau peaks $2 \theta=39,46$ and $68^{\circ}$ obtained according to the peak of the evaluated platinum using the Scherrer equation; their values are given in Table 2.

Table 2. Average crystallite size (D) for the $\mathrm{Pt} / \mathrm{C}, \mathrm{Pt}_{1} \mathrm{Sn}_{1} / \mathrm{C}$, $\mathrm{Pt}_{2} \mathrm{Sn}_{1} / \mathrm{C}, \mathrm{Pt}_{3} \mathrm{Sn}_{1} / \mathrm{C}, \mathrm{Pt}_{3} \mathrm{Sn}_{1-} 5 \% \mathrm{NR} \mathrm{CeO}_{2} / \mathrm{C}, \mathrm{Pt}_{3} \mathrm{Sn}_{1-} 10 \% \mathrm{NRCeO}_{2} / \mathrm{C}$, $\mathrm{Pt}_{3} \mathrm{Sn}_{1-} 20 \% \mathrm{NRCeO}_{2} / \mathrm{C}$ electrocatalysts

\begin{tabular}{lccc}
\hline Electrocatalyst & $\begin{array}{c}\text { Average } \\
\text { crystalline } \\
\text { size } 39^{\circ} / \mathrm{nm}\end{array}$ & $\begin{array}{c}\text { Average } \\
\text { crystalline } \\
\text { size } 46^{\circ} / \mathrm{nm}\end{array}$ & $\begin{array}{c}\text { Average } \\
\text { crystalline } \\
\text { size } 68^{\circ} / \mathrm{nm}\end{array}$ \\
\hline $\mathrm{Pt} / \mathrm{C}$ & 1 & 1 & 1 \\
$\mathrm{Pt}_{1} \mathrm{Sn}_{1} / \mathrm{C}$ & 2 & 1 & 3 \\
$\mathrm{Pt}_{2} \mathrm{Sn}_{1} / \mathrm{C}$ & 4 & 3 & 2 \\
$\mathrm{Pt}_{3} \mathrm{Sn}_{1} / \mathrm{C}$ & 5 & 4 & 3 \\
$\mathrm{Pt}_{3} \mathrm{Sn}_{1-5 \% \mathrm{NRCeO}_{2} / \mathrm{C}}$ & 5 & 4 & 3 \\
$\mathrm{Pt}_{3} \mathrm{Sn}_{1-1} 10 \% \mathrm{NRCeO}_{2} / \mathrm{C}$ & 5 & 4 & 3 \\
$\mathrm{Pt}_{3} \mathrm{Sn}_{1-2} 20 \% \mathrm{NRCeO}_{2} / \mathrm{C}$ & 5 & 4 & 3 \\
\hline
\end{tabular}

The average crystallite size was close to $1 \mathrm{~nm}$ for the platinum and carbon electrocatalysts, with an increase in crystallite size observed for the electrocatalysts with added tin; however, the $\mathrm{Pt}_{1} \mathrm{Sn}_{1} / \mathrm{C}$ and $\mathrm{Pt}_{2} \mathrm{Sn}_{1} / \mathrm{C}$ materials with smaller platinum masses presented sizes close to $3 \mathrm{~nm}$.

The electrocatalysts with a $3: 1$ platinum to tin mass ratio, respectively, showed a mean increase in crystallite size to approximately $4 \mathrm{~nm}$ for both nanorods and materials with nanorods in their composition. This characteristic corroborates the sharpness of the peaks observed in the diffractograms in Figures 1 and 2, since better defined peaks are present for materials with larger average crystallite sizes, whereas larger peaks and less intense peaks refer to particles of smaller size, as observed in the diffractograms for materials with lower mass ratios between $\mathrm{Pt}$ and $\mathrm{Sn}$ and $\mathrm{Pt} / \mathrm{C}$ material. ${ }^{40}$

By means of XRD, Beyhan et al. ${ }^{8}$ observed that Pt and PtSn-type electrocatalysts supported on carbon contain Pt with a fcc structure with crystallite sizes of approximately 2-6 $\mathrm{nm}$.

Figures $3 \mathrm{a}, 3 \mathrm{~b}$ and $3 \mathrm{c}$ presents TEM images of the carbon-supported Pt, PtSn (3:1) and PtSn_20\% $\mathrm{NRCeO}_{2}$ nanoelectrocatalyts and their corresponding sizedistribution histograms.
It was observed that the catalyst composed of $\mathrm{Pt} / \mathrm{C}$ (Figure 3a) presented relatively smaller nanoparticles $(5 \pm 2 \mathrm{~nm})$ than others electrocatalysts, with nucleation more evidently represented by the dark spots of the image. In the $\mathrm{Pt}_{3} \mathrm{Sn}_{1} / \mathrm{C}$ (Figure 3b) and $\mathrm{Pt}_{3} \mathrm{Sn}_{1-} 20 \% \mathrm{NRCeO}_{2} / \mathrm{C}$ (Figure 3c) nanoelectrocatalysts, larger nanoparticles were formed at $10 \pm 5$ and $19 \pm 4 \mathrm{~nm}$, respectively.

However, the $\mathrm{Pt} / \mathrm{C}$ electrocatalyst nanoparticles were better defined due to the action of the reducing agent used in the synthesis (sodium borohydride) ${ }^{26}$ exclusively in the platinum, resulting in a more accelerated reduction and formation of smaller nanoparticles. For the catalysts in which tin was present, reduction occurred more slowly, resulting in larger nanoparticles.

The $\mathrm{CeO}_{2}$ nanorods also contribute to the considerable increase in the size of the nanoparticles due to their morphologies showing high aspect ratios (ratio between length and width), ${ }^{20}$ in accordance with studies carried out by Pinheiro et al. ${ }^{20}$ for ceria high aspect ratio nanostructures supported on carbon. For this reason, the data observed by TEM corroborate with the results evaluated and observed by X-ray diffraction in relation to the particle size.

An interaction between the platinum, tin and the $\mathrm{CeO}_{2}$ nanorods was indicated, showing that nanoparticles agglomerate, as can be seen in Figure 3e. The evidence for the presence of $\mathrm{CeO}_{2}$ nanorods can be verified in Figure 4, which also shows analysis based on EDS. Figure 4 shows the transmission microscopy performed on the material $\mathrm{Pt}_{3} \mathrm{Sn}_{1} 20 \% \mathrm{NRCeO}_{2} / \mathrm{C}$ in which it is possible to evidence the presence of the $\mathrm{CeO}_{2}$ characteristic nanorods structure characterized by high aspect ratio ('a' region). In addition, the analysis of dispersive energy spectroscopy for this same material was carried out in regions ' $a$ ' and ' $b$ ' shown in Figure 4. Region ' $b$ ' of the microscopy image shows a nanoparticle with rounded morphology; this same region showed intense platinum peaks, as verified in the EDS analysis. However, region ' $a$ ' of the microscopy image, which presents a distinct morphology characterizing the $\mathrm{CeO}_{2}$ nanorods, revealed intense cerium and tin peaks in the EDS spectrum, since both metals constitute and act in a synergic way in the electrocatalysts.

\section{Electrochemical characterization and activities of the} electrocatalysts

Electrochemical characterization of the materials by means of cyclic voltammetries, known as "blank" voltages, is presented in Figures 5 and 6. These curves allow to clarify the surface properties of the electrocatalysts, making it possible to evaluate the region known as "hydrogen region". The negative sweep, also called the cathodic process, 


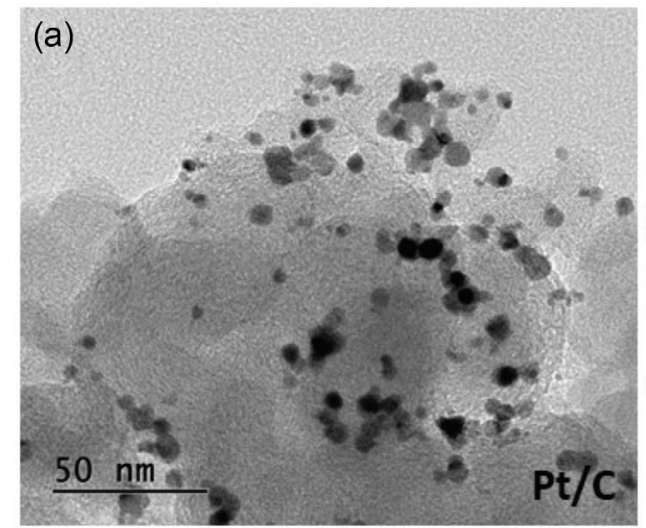

(b)
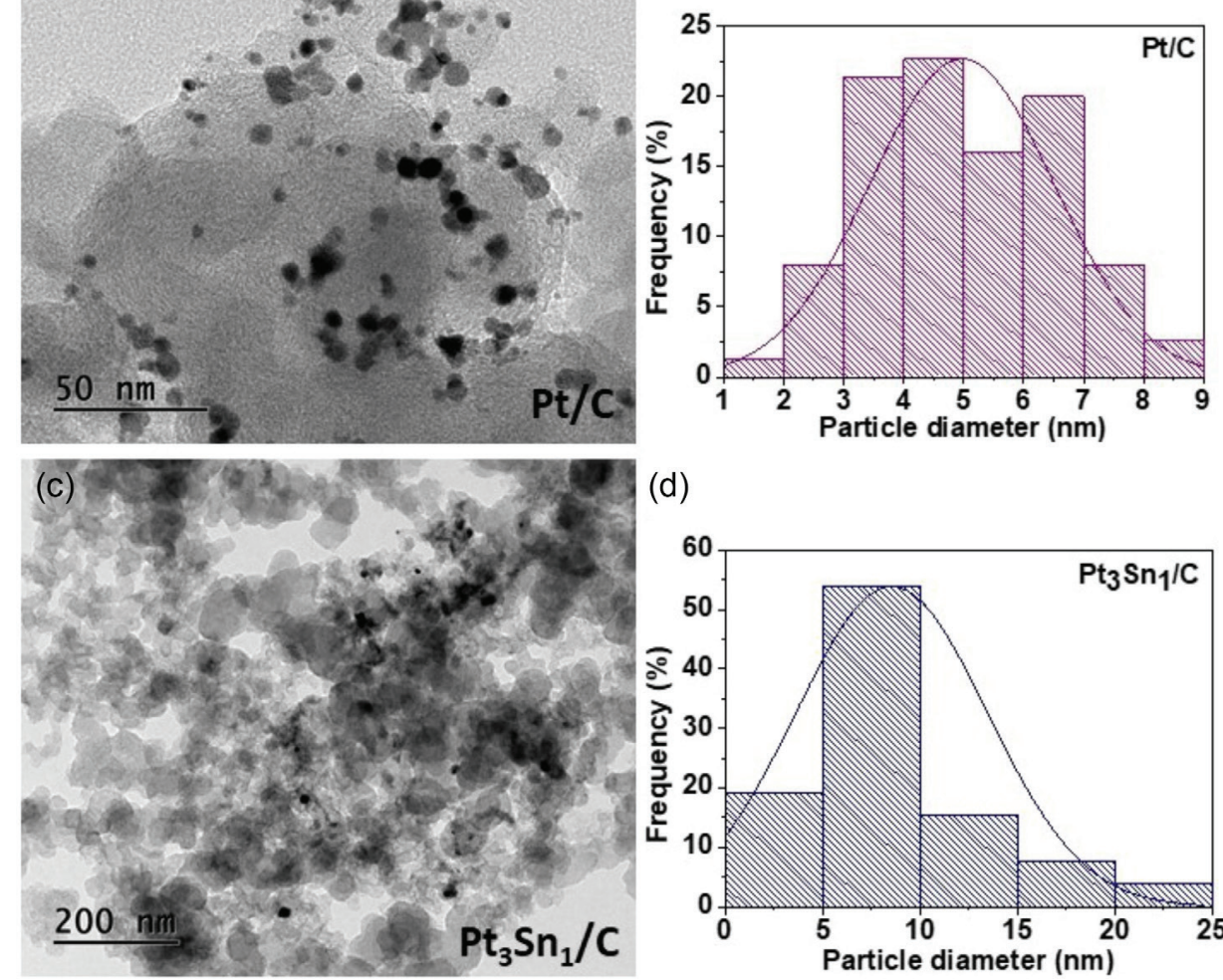

(d)
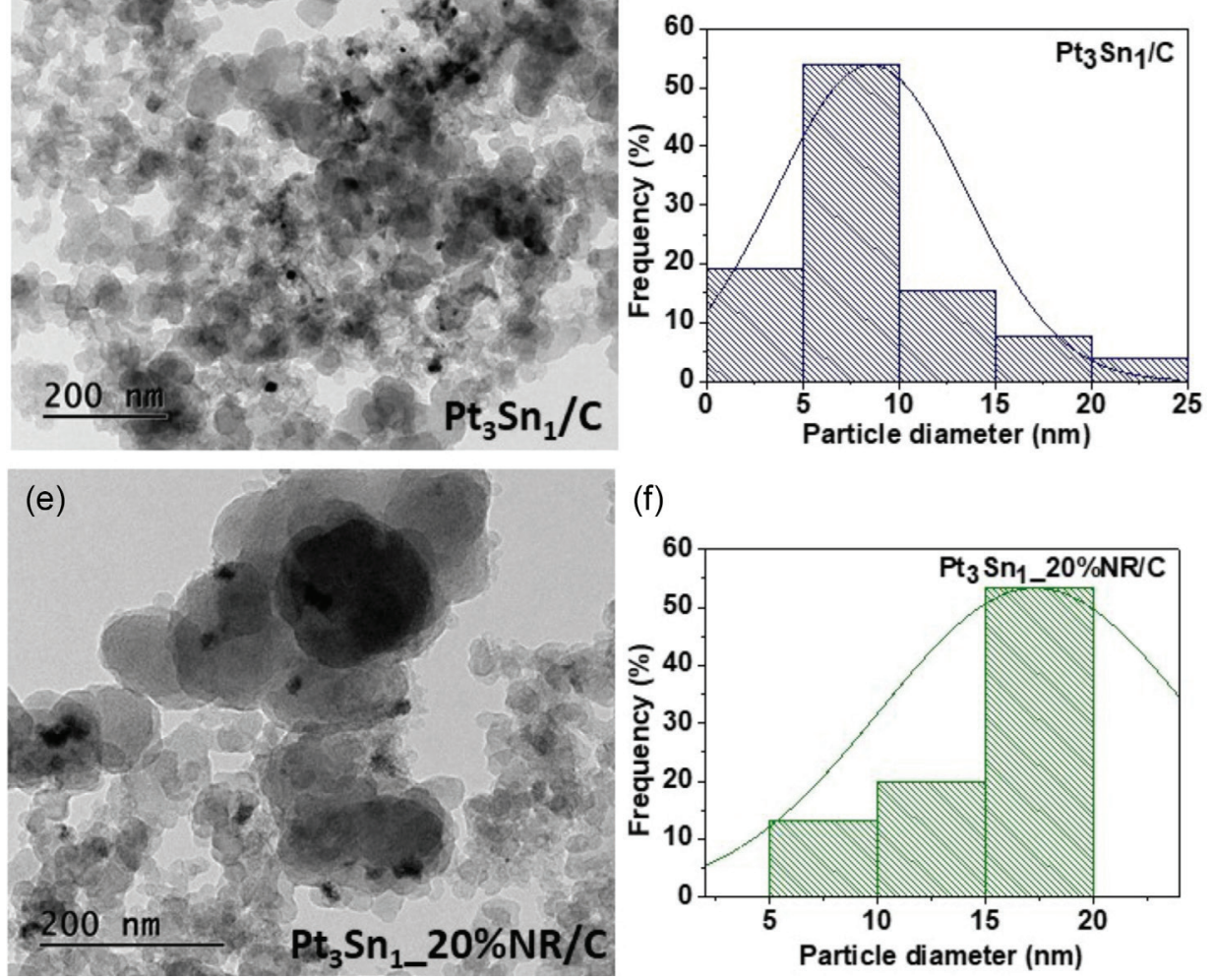

(f)

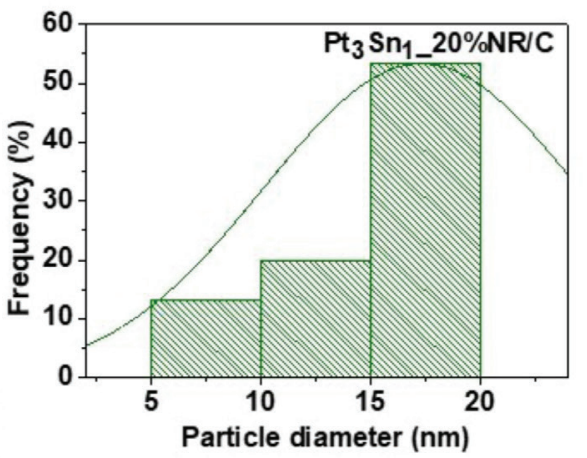

Figure 3. (a) TEM image of $\mathrm{Pt} / \mathrm{C}$; (b) size-distribution histogram for $\mathrm{Pt} / \mathrm{C}$; (c) TEM image of $\mathrm{Pt}_{3} \mathrm{Sn}_{1} / \mathrm{C}$; (d) size-distribution histogram for $\mathrm{Pt} \mathrm{Sn}_{1} / \mathrm{C}$; (e) TEM image of $\mathrm{Pt}_{3} \mathrm{Sn}_{1-} 20 \% \mathrm{NRCeO}_{2} / \mathrm{C}$; (f) size-distribution histogram for $\mathrm{Pt}_{3} \mathrm{Sn}_{1-} 20 \% \mathrm{NRCeO}_{2} / \mathrm{C}$.

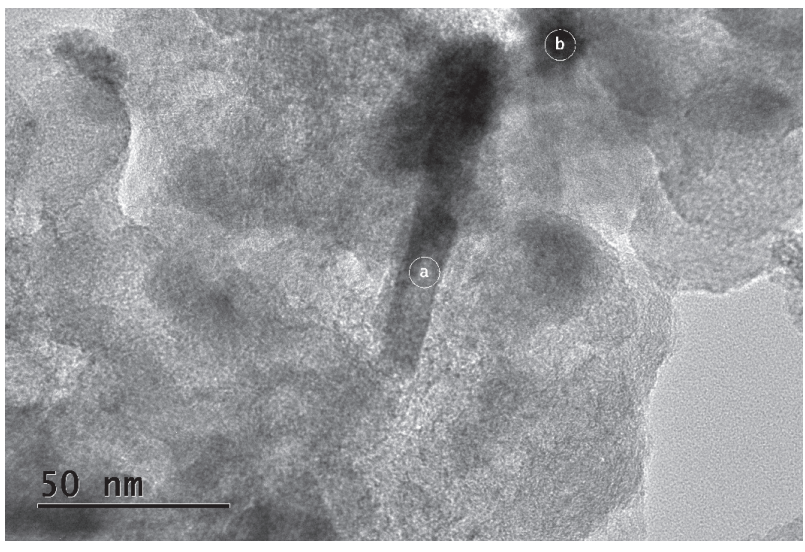

Figure 4. TEM image for $\mathrm{Pt}_{3} \mathrm{Sn}_{1-} 20 \% \mathrm{NRCeO}_{2} / \mathrm{C}$. represents the adsorption of atomic hydrogen formed by the reduction of $\mathrm{H}^{+}$, and the positive sweep of the cyclic voltammetry represents the oxidation of adsorbed atomic hydrogen formed in the cathodic stage. ${ }^{4}$

For these experiments the conditions were: $0.5 \mathrm{~mol} \mathrm{~L}^{-1}$ sulfuric acid solution $\left(\mathrm{H}_{2} \mathrm{SO}_{4} 0.5 \mathrm{~mol} \mathrm{~L}^{-1}\right), 10 \mathrm{mV} \mathrm{s}^{-1}$ scanning rate, reversible hydrogen electrode (RHE) as reference electrode and platinum counter electrode. The normalization to elaborate the curves was carried out in mass ratio.

According to Figure 5 we can see peaks related to the desorption/adsorption region of hydrogen, between 0.05 and $0.4 \mathrm{~V}$ related to the presence of free platinum active sites for hydrogen desorption/adsorption and a widening 


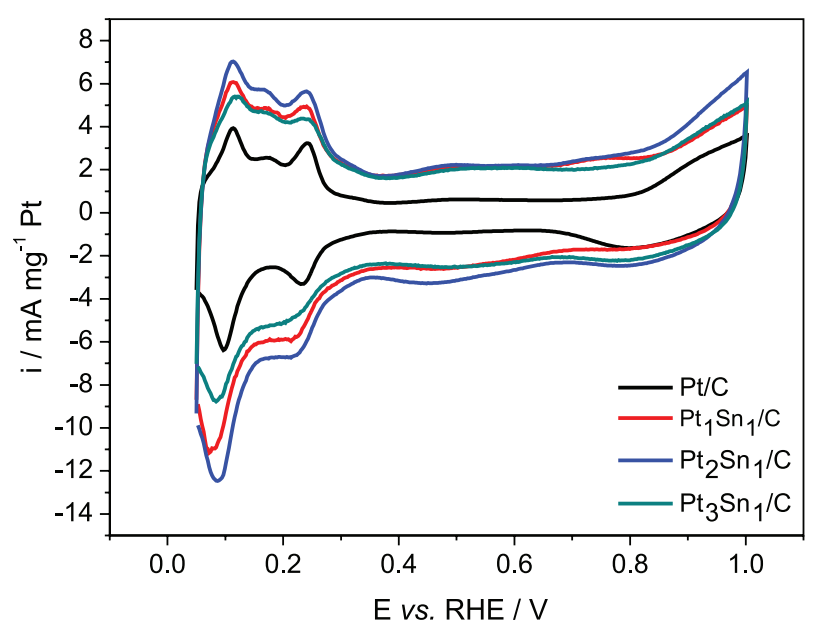

Figure 5. Cyclic voltammograms for the electrocatalysts prepared using the chemical reduction method via sodium borohydride at a scan rate of $10 \mathrm{mV} \mathrm{s}^{-1}$ in a $0.5 \mathrm{~mol} \mathrm{~L}^{-1} \mathrm{H}_{2} \mathrm{SO}_{4}$ solution.

in the region of 0.4 and $0.7 \mathrm{~V}$, known as the double electric layer region, for the materials in which the tin secondary metal was present, in relation to the $\mathrm{Pt} / \mathrm{C}$ electrocatalyst. ${ }^{41}$

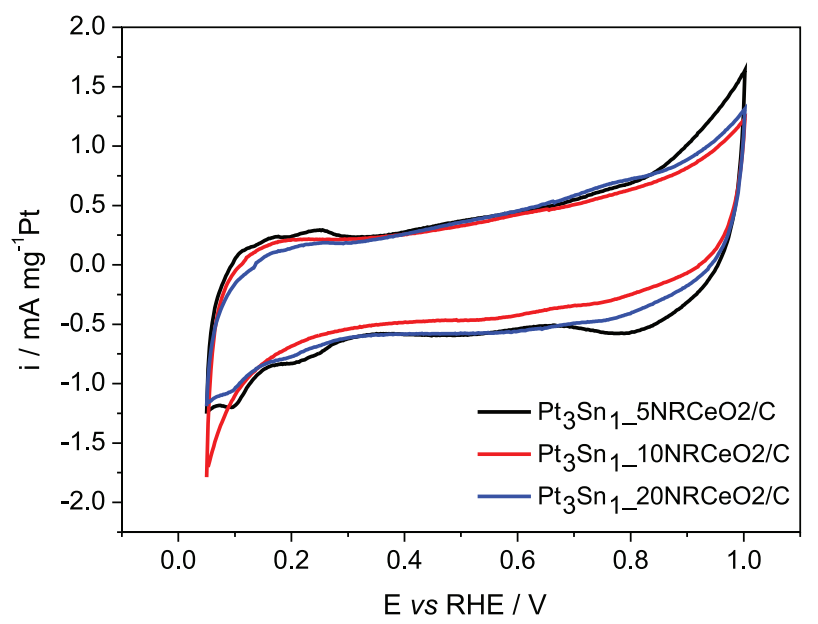

Figure 6. Cyclic voltammograms for the $\mathrm{Pt}_{3} \mathrm{Sn}_{1} 5 \% \mathrm{NRCeO}_{2} / \mathrm{C}$, $\mathrm{Pt}_{3} \mathrm{Sn}_{1-} 10 \% \mathrm{NRCeO}_{2} / \mathrm{C}$ and $\mathrm{Pt}_{3} \mathrm{Sn}_{1-} 20 \% \mathrm{NRCeO}_{2} / \mathrm{C}$ electrocatalysts prepared using the chemical reduction method via sodium borohydride at a scan rate of $10 \mathrm{mV} \mathrm{s}^{-1}$ in a $0.5 \mathrm{~mol} \mathrm{~L}^{-1} \mathrm{H}_{2} \mathrm{SO}_{4}$ solution.

Figure 6 refers to the electrochemical characterization of materials $\mathrm{Pt}_{3} \mathrm{Sn}_{1 \_} 5 \% \mathrm{NRCeO}_{2} / \mathrm{C} ; \mathrm{Pt}_{3} \mathrm{Sn}_{1-} 10 \% \mathrm{NRCeO}_{2} / \mathrm{C}$; $\mathrm{Pt}_{3} \mathrm{Sn}_{1} \_20 \% \mathrm{NRCeO}_{2} / \mathrm{C}$, prepared with the results of cyclic voltammetries under the same conditions for the materials without the addition of $\mathrm{CeO}_{2} \mathrm{NR}$. The hydrogen desorption/ adsorption region had less defined peaks for materials containing $\mathrm{NR}$ of $\mathrm{CeO}_{2}$ in their composition, indicating a greater presence of oxygen species, in potentials less positive than $0.4 \mathrm{~V}^{42}$

Tin secondary metal has properties of forming oxygen species at less positive potentials when compared to pure platinum catalysts. The electrocatalysts with secondary metals modify the energy levels of the $5 \mathrm{~d}$ band of platinum, changing their electronic density (electronic effect), thus improving the activity of the electrocatalyst in the oxidation of the fuel, however, in this work the bifunctional mechanism is the operant since there is no formation of an alloy according to the our XRD results. ${ }^{41}$

The activity of the synthesized materials was evaluated in relation to the catalytic ethanol oxidation reaction (Figures 7 and 8), in which the onset oxidation potentials were verified. In Figure 7, it is noted that the material composed of only platinum and carbon presented a value of $0.51 \mathrm{~V} v s$. RHE for the onset potential of EOR, while the binary materials containing platinum and tin showed less positive potentials of $0.24 \mathrm{~V} v s$. RHE for the $\mathrm{Pt}_{1} \mathrm{Sn}_{1} / \mathrm{C}$ and $\mathrm{Pt}_{2} \mathrm{Sn}_{1} / \mathrm{C}$ electrocatalysts and $0.15 \mathrm{~V}$ for the $\mathrm{Pt}_{3} \mathrm{Sn}_{1} / \mathrm{C}$ material.

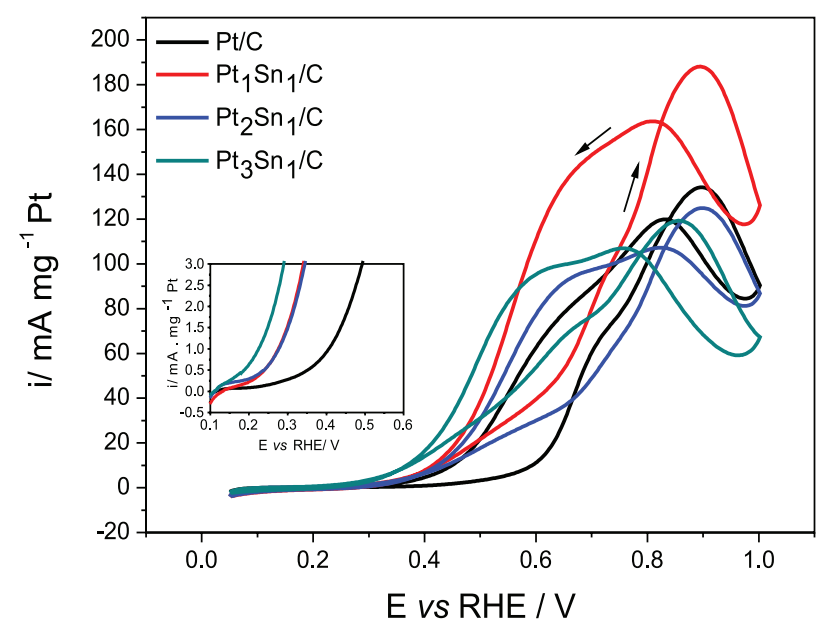

Figure 7. Cyclic voltammograms for the electrocatalysts prepared using the chemical reduction method via sodium borohydride at a scan rate of $10 \mathrm{mV} \mathrm{s}^{-1}$ in a $1 \mathrm{~mol} \mathrm{~L}^{-1} \mathrm{CH}_{3} \mathrm{CH}_{2} \mathrm{OH}+0.5 \mathrm{~mol} \mathrm{~L}^{-1} \mathrm{H}_{2} \mathrm{SO}_{4}$ solution.

Silva et al. ${ }^{26}$ were able to obtain oxidation initiation potentials of approximately $0.23 \mathrm{~V}$ for $\mathrm{SnO}_{2} @ \mathrm{Pt} / \mathrm{C}$ materials and $0.37 \mathrm{~V}$ for $\mathrm{Pt} / \mathrm{C}$. The onset oxidation potential values are highly affected by the incorporation of tin in the electrocatalyst, as observed in the experimental results shown in that work.

Figure 8 shows a comparison of the electrocatalytic activity with $\mathrm{CeO}_{2} \mathrm{NR}$ in relation to the binary material $\mathrm{Pt}_{3} \mathrm{Sn}_{1} / \mathrm{C}$. It was noted that the material $\mathrm{Pt}_{3} \mathrm{Sn}_{1-} 20 \%$ $\mathrm{NRCeO}_{2} / \mathrm{C}$ exhibited a potential of $0.18 \mathrm{~V} v s$. RHE, which is less positive than the others $(0.64 \mathrm{~V}$ vs. RHE for $\mathrm{Pt}_{3} \mathrm{Sn}_{1-} 10 \% \mathrm{NRCeO}_{2} / \mathrm{C}$ and $0.32 \mathrm{~V}$ vs. RHE for $\mathrm{Pt}_{3} \mathrm{Sn}_{1-} 5 \% \mathrm{NRCeO}_{2} / \mathrm{C}$ ) and very close to $0.15 \mathrm{~V} v s$. RHE relative to the material $\mathrm{Pt}_{3} \mathrm{Sn}_{1} / \mathrm{C}$, corroborating with the literature, given the study by de Souza et al. ${ }^{41}$ which showed that as the charge on $\mathrm{Ce}$ is increased, the potentials for the onset of ethanol oxidation decreased and 
the breakdown of the $\mathrm{C}-\mathrm{C}$ bond was facilitated. The first peak (at. $0.6 \mathrm{~V} v s$. RHE) corresponds to the oxidation of ethanol to $\mathrm{CO}_{2}$ and the second peak (at. $0.9 \mathrm{~V}$ ) refers to the formation of acetaldehyde and acetic acid..$^{9,26}$

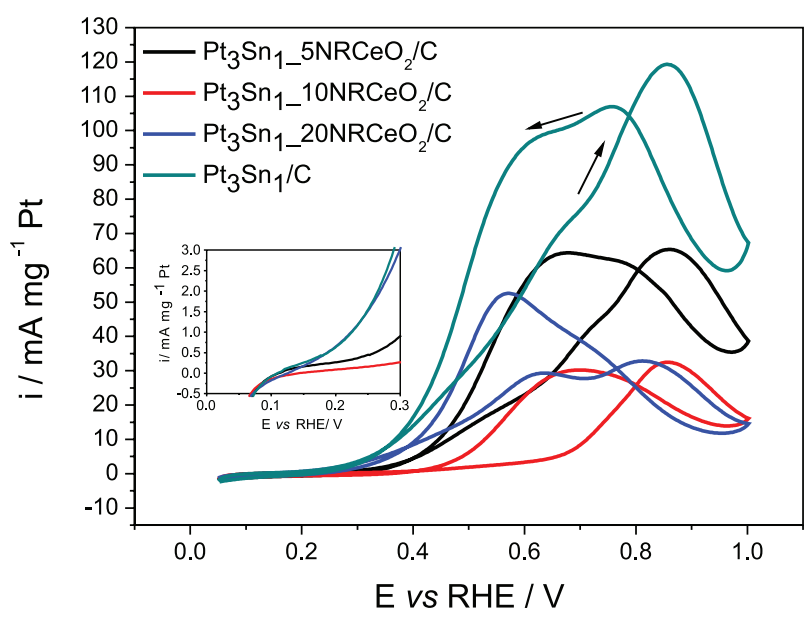

Figure 8. Cyclic voltammograms for the $\mathrm{Pt}_{3} \mathrm{Sn}_{1} / \mathrm{C}, \mathrm{Pt}_{3} \mathrm{Sn}_{1-} 5 \% \mathrm{NRCeO}_{2} / \mathrm{C}$, $\mathrm{Pt}_{3} \mathrm{Sn}_{1-} 10 \% \mathrm{NRCeO}_{2} / \mathrm{C}$ and $\mathrm{Pt}_{3} \mathrm{Sn}_{1-} 20 \% \mathrm{NRCeO}_{2} / \mathrm{C}$ electrocatalysts prepared using the chemical reduction method via sodium borohydride at a scan rate of $10 \mathrm{mV} \mathrm{s}^{-1}$ in a $1 \mathrm{~mol} \mathrm{~L}^{-1} \mathrm{CH}_{3} \mathrm{CH}_{2} \mathrm{OH}+0.5 \mathrm{~mol} \mathrm{~L}^{-1}$ $\mathrm{H}_{2} \mathrm{SO}_{4}$ solution.

To evaluate the electrocatalytic activity, chronoamperometric measurements were carried out under a fixed potential of $0.5 \mathrm{~V} v s$. RHE for a period of $1800 \mathrm{~s}$, in a $0.5 \mathrm{~mol} \mathrm{~L}^{-1} \mathrm{H}_{2} \mathrm{SO}_{4}$ medium, as shown in Figures 9 and 10. It was observed that the materials containing platinum and tin showed a higher current normalized by the $\mathrm{Pt}$ mass values compared with the catalyst consisting only of platinum and carbon support, enabling the synthesis of such catalysts by the proposed method and reducing the amount of platinum used. It was also possible to observe that among the electrocatalysts containing nanorods, the $\mathrm{Pt}_{3} \mathrm{Sn}_{1} \_20 \% \mathrm{NRCeO}_{2} / \mathrm{C}$ presented higher current values in $\mathrm{mA} \mathrm{mg}{ }^{-1} \mathrm{Pt}$; that is, it is possible to significantly reduce the amount of platinum and tin and still maintain activity in the oxidative process of the fuel.

The normalized per milligram of platinum value for the $\mathrm{Pt}_{3} \mathrm{Sn}_{1} / \mathrm{C}$ material represented a value of $7.5 \mathrm{~mA}$, in contrast, the $\mathrm{Pt}_{3} \mathrm{Sn}_{1} \_20 \% \mathrm{NRCeO}_{2} / \mathrm{C}$ material had a value of $4.8 \mathrm{~mA}$ under the same operating conditions, surpassing the $2.65 \mathrm{~mA}$ current obtained with the $\mathrm{Pt} / \mathrm{C}$ electrocatalyst. In addition, both the $\mathrm{Pt}_{3} \mathrm{Sn}_{1} / \mathrm{C}$ material and the $\mathrm{Pt}_{3} \mathrm{Sn}_{1-} 20 \% \mathrm{NRCeO}_{2} / \mathrm{C}$ material presented a slower decay in the current-time curves during ethanol electrooxidation in acid media, as verified by de Souza $e t ~ a l .{ }^{41}$ in studies on the contribution of ceria in electrocatalysts of the $\mathrm{PtSn} / \mathrm{C}+\mathrm{Ce} / \mathrm{C}$ type.

Among the materials containing the NR, the $\mathrm{Pt}_{3} \mathrm{Sn}_{1} \_20 \% \mathrm{NRCeO}_{2} / \mathrm{C}$ catalyst had the highest degree of metallic load replacement and revealed that it was

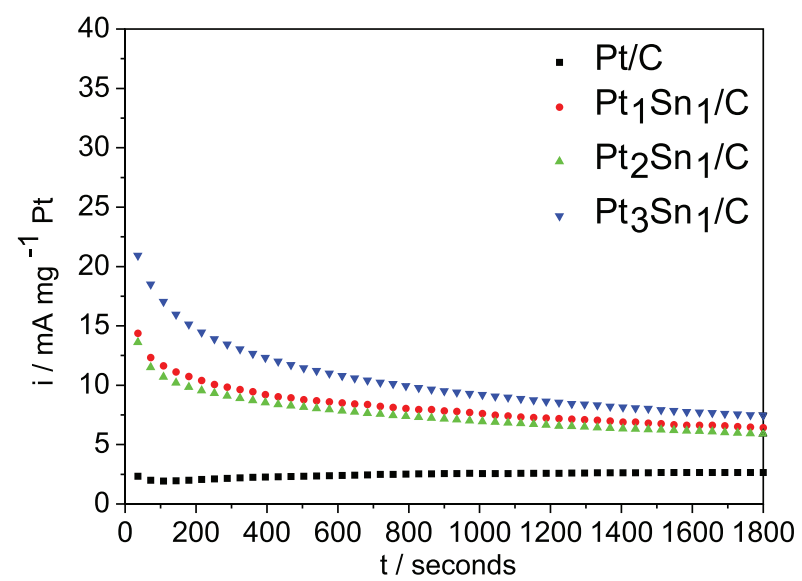

Figure 9. Chronoamperometric curves for the EOR using $\mathrm{Pt} / \mathrm{C}, \mathrm{Pt}_{3} \mathrm{Sn}_{1} / \mathrm{C}$, $\mathrm{Pt}_{2} \mathrm{Sn}_{1} / \mathrm{C}, \mathrm{Pt}_{1} \mathrm{Sn}_{1} / \mathrm{C}$ electrocatalysts prepared using the chemical reduction method via sodium borohydride in $1 \mathrm{~mol} \mathrm{~L}^{-1} \mathrm{CH}_{3} \mathrm{CH}_{2} \mathrm{OH}+0.5 \mathrm{~mol} \mathrm{~L}^{-1}$ $\mathrm{H}_{2} \mathrm{SO}_{4}$ at an applied potential of $0.5 \mathrm{~V}$ for $1800 \mathrm{~s}$.

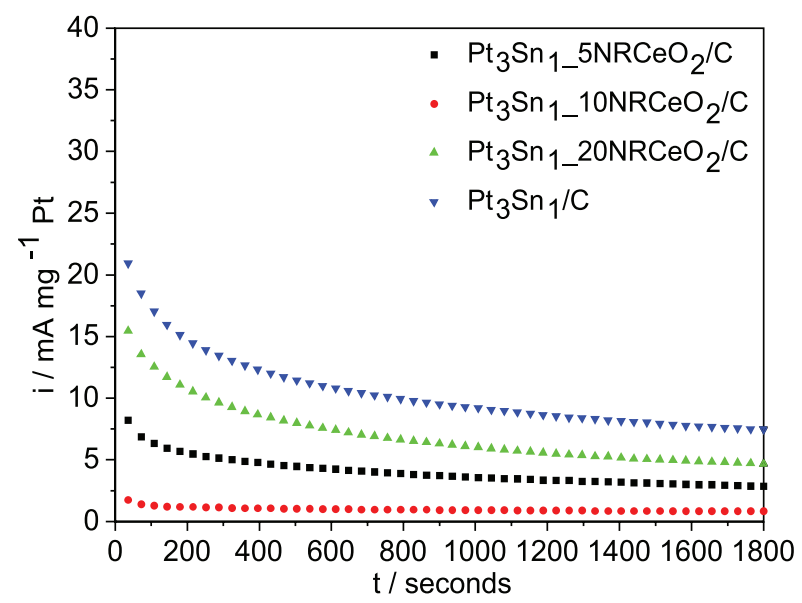

Figure 10. Chronoamperometric curves for the EOR using $\mathrm{Pt}_{3} \mathrm{Sn}_{1} / \mathrm{C}$, $\mathrm{Pt}_{3} \mathrm{Sn}_{1-} 5 \% \mathrm{NRCeO}_{2} / \mathrm{C}, \mathrm{Pt}_{3} \mathrm{Sn}_{1-} 10 \% \mathrm{NRCeO}_{2} / \mathrm{C}$ and $\mathrm{Pt}_{3} \mathrm{Sn}_{1} \_20 \% \mathrm{NRCeO}_{2} / \mathrm{C}$ electrocatalysts prepared using the chemical reduction method via sodium borohydride in $1 \mathrm{~mol} \mathrm{~L}^{-1} \mathrm{CH}_{3} \mathrm{CH}_{2} \mathrm{OH}+0.5 \mathrm{~mol} \mathrm{~L}^{-1} \mathrm{H}_{2} \mathrm{SO}_{4}$ at an applied potential of $0.5 \mathrm{~V}$ for $1800 \mathrm{~s}$.

composed of the most appropriate proportion in terms of the obtained current.

From the results obtained in the chronoamperometric measurements for $0.5 \mathrm{~V} v s$. RHE, it was determined to evaluate the catalytic activity in less positive potentials for the electrocatalysts that showed higher current values in their composition class.

For this reason, chronoamperometric measurements were carried out at potentials of 0.3 and $0.4 \mathrm{~V}$ for the electrocatalysts consisting of $\mathrm{Pt}_{3} \mathrm{Sn}_{1} / \mathrm{C}$ and $\mathrm{Pt}_{3} \mathrm{Sn}_{1-} 20 \% \mathrm{NRCeO}_{2} / \mathrm{C}$, respectively, and not containing nanorods. The curves obtained from these experiments are shown in Figure 11.

From the chronoamperometric measurements shown above, it is noted that at $0.3 \mathrm{~V} v s$. RHE, both electrocatalysts presented current values very close to zero due to the 


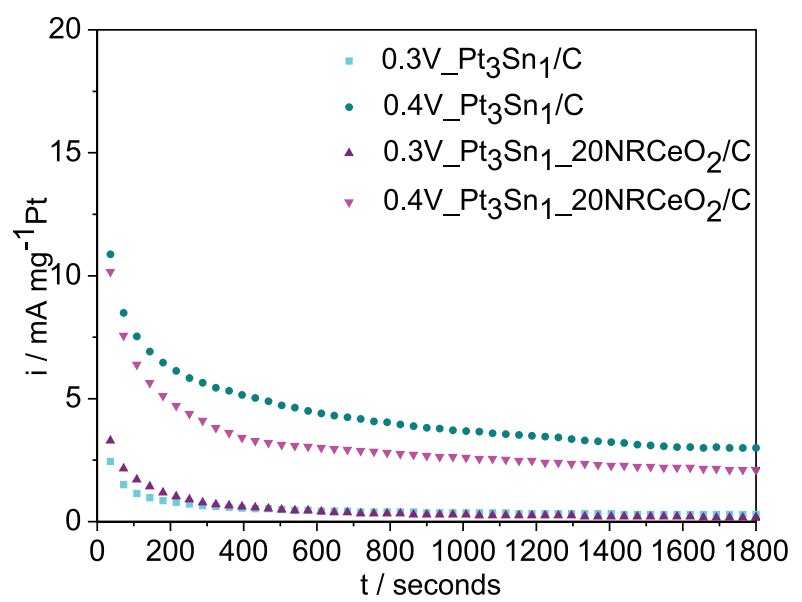

Figure 11. Chronoamperometric curves for the EOR using $\mathrm{Pt}_{3} \mathrm{Sn}_{1} / \mathrm{C}$ and $\mathrm{Pt}_{3} \mathrm{Sn}_{1} 20 \% \mathrm{NRCeO}_{2} / \mathrm{C}$ electrocatalysts prepared using the chemical reduction method via sodium borohydride in $1 \mathrm{~mol} \mathrm{~L}^{-1} \mathrm{CH}_{3} \mathrm{CH}_{2} \mathrm{OH}+$ $0.5 \mathrm{~mol} \mathrm{~L}^{-1} \mathrm{H}_{2} \mathrm{SO}_{4}$ at an applied potentials of 0.3 and $0.4 \mathrm{~V}$ for $1800 \mathrm{~s}$.

potential being relatively low, representing $0.27 \mathrm{~mA} \mathrm{mg}^{-1}$ $\mathrm{Pt}$ for the $\mathrm{Pt}_{3} \mathrm{Sn}_{1} / \mathrm{C}$ material and $0.20 \mathrm{~mA} \mathrm{mg}^{-1} \mathrm{Pt}$ for $\mathrm{Pt}_{3} \mathrm{Sn}_{1} \_20 \% \mathrm{NRCeO}_{2} / \mathrm{C}$, as detailed in Table 3.

Table 3. Current values for $1800 \mathrm{~s}$ of ethanol oxidative processing at 0.3 and $0.4 \mathrm{~V}$

\begin{tabular}{lcc}
\hline Electrocatalyst & $\begin{array}{c}\text { Current for } 1800 \mathrm{~s} \\
(0.3 \mathrm{~V} \mathrm{vs.} \mathrm{RHE}) / \\
\left(\mathrm{mA} \mathrm{mg}{ }^{-1} \mathrm{Pt}\right)\end{array}$ & $\begin{array}{c}\text { Current for } 1800 \mathrm{~s} \\
(0.4 \mathrm{~V} v s . \mathrm{RHE}) / \\
\left(\mathrm{mA} \mathrm{mg}{ }^{-1} \mathrm{Pt}\right)\end{array}$ \\
\hline $\mathrm{Pt}_{3} \mathrm{Sn}_{1} / \mathrm{C}$ & 0.27 & 2.98 \\
$\mathrm{Pt}_{3} \mathrm{Sn}_{1-2} 20 \% \mathrm{NRCeO}_{2} / \mathrm{C}$ & 0.20 & 2.13 \\
\hline
\end{tabular}

RHE: reversible hydrogen electrode.

At $0.4 \mathrm{~V}$, it was observed that the electrocatalyst containing $20 \%$ of cerium oxide NR revealed current values very close to the current values measured for the material that did not present NR in its constitution according to the green and pink colored curves.

The loads taken from high cost metals to materials containing $20 \%$ of ceria NR are significant, representing $4 \%$ of the total metal load, allowing one to conclude that even with this change in the composition of the electrocatalyst, it is possible to check for current values very close to that present for materials with more promising activity according to the literature, ${ }^{7}$ leading to the conclusion that cerium oxide had a fundamental role in the oxidation of ethanol in $0.4 \mathrm{~V} v s$. RHE of a fixed potential.

\section{CO stripping}

Since the $\mathrm{CO}$ is an intermediary that promotes catalytic poisoning, the activity of the catalysts for oxidation of this compound is evaluated by means of the cyclic voltammetry technique with $\mathrm{CO}$ stripping with the purpose of evaluating the behavior of electrocatalysts for this intermediary oxidation. ${ }^{11,26}$ The areas related to the $\mathrm{CO}$ were calculated, making it possible to estimate the load of CO. The load of $\mathrm{CO}$ is a value that represents the activity of the catalyst for oxidation of this intermediate (CO) according to calculations of the electrochemically active surface area.

Figure 12 shows the cyclic voltammetry data for $\mathrm{Pt} / \mathrm{C}$ (a), $\mathrm{Pt}_{1} \mathrm{Sn}_{1} / \mathrm{C}$ (b), $\mathrm{Pt}_{2} \mathrm{Sn}_{1} / \mathrm{C}$ (c) and $\mathrm{Pt}_{3} \mathrm{Sn}_{1} / \mathrm{C}$ (d), in which the black-colored curves were obtained in the first voltammetry cycle in the abovementioned cell conditions, with a sweep rate of $10 \mathrm{mV} \mathrm{s}^{-1}$ with the red-colored curves obtained shortly after the oxidation of CO. Peaks related to the hydrogen desorption/adsorption region, between 0.05 and $0.4 \mathrm{~V}$ are related to the presence of free platinum active sites for hydrogen desorption/adsorption. ${ }^{7}$

Figure 13 shows voltammograms for $\mathrm{CO}$ oxidation for $\mathrm{Pt}_{3} \mathrm{Sn}_{1-} 5 \% \mathrm{NRCeO}_{2} / \mathrm{C}$ (a) catalysts; $\mathrm{Pt}_{3} \mathrm{Sn}_{1} \_10 \% \mathrm{NRCeO}_{2} / \mathrm{C}$ (b) and $\mathrm{Pt}_{3} \mathrm{Sn}_{1} \_20 \% \mathrm{NRCeO}_{2} / \mathrm{C}$ (c). There is a significant difference in the intensity of the peak formed from the oxidative processes of the catalyst containing $20 \%$ of nanorods in its composition.

From the cyclic voltammetry for CO stripping, it was possible to evaluate the charge values for $\mathrm{CO}(\mathrm{Q})$, onset potential and $\mathrm{CO}$ oxidation potential. The $\mathrm{CO}$ charge is the result of the ratio between the oxidation peak area of $\mathrm{CO}$ and the scan rate in $\mathrm{V} \mathrm{s}^{-1} ; 9,10,16$ the other data were obtained by the evaluation of the voltammogram with the aid of the program OriginPro 2015. All the values obtained are shown in Table 4.

It is noted that the material containing $20 \% \mathrm{NR}$ showed the greatest value for $\mathrm{CO}$ charge, corresponding to $2.5 \times 10^{-3} \mathrm{C}$, as verified in Table 4 , in addition to presenting an onset potential for $\mathrm{CO}$ oxidation corresponding to $0.16 \mathrm{~V}$ vs. RHE, while the other catalysts presented an onset potential of approximately $0.28 \mathrm{~V}$. Parreira et al. ${ }^{9}$ evaluated the activity for the oxidation of $\mathrm{CO}$ with the use of commercial electrocatalysts and composition similar to those studied in this article; however, the onset oxidation potentials for the materials presented here were significantly lower than those mentioned in the literature, indicating a higher electrocatalytic activity for $\mathrm{CO}$ oxidation.

This indicates greater catalytic activity for $\mathrm{CO}$ oxidation with the use of this material. With this, it is possible to oxidize the intermediate $\mathrm{CO}$ compound in considerably less positive potentials, due to the presence of oxygenated species facilitating the $\mathrm{CO}$ oxidation to $\mathrm{CO}_{2}$ and reducing catalytic poisoning.

According to studies performed by Asgardi et al..${ }^{43}$ the presence of tin in the composition of the material produces an oxyphilic increase in the catalyst; that is to say, the 

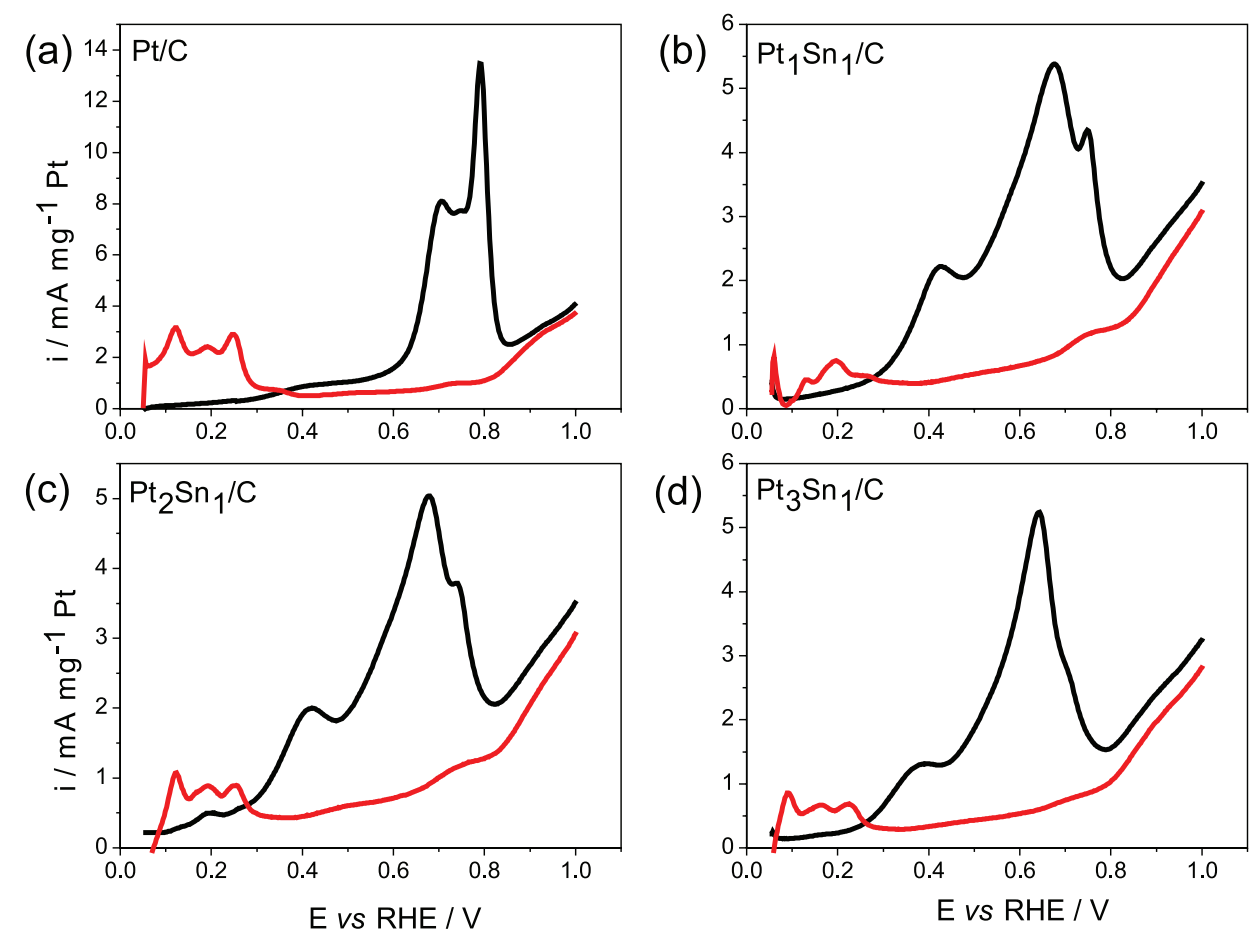

Figure 12. CO stripping curves for (a) $\mathrm{Pt} / \mathrm{C}$; (b) $\mathrm{Pt}_{1} \mathrm{Sn}_{1} / \mathrm{C}$; (c) $\mathrm{Pt}_{2} \mathrm{Sn}_{1} / \mathrm{C}$; (d) $\mathrm{Pt}_{3} \mathrm{Sn}_{1} / \mathrm{C}$ electrocatalysts in $0.5 \mathrm{~mol} \mathrm{~L}^{-1} \mathrm{H}_{2} \mathrm{SO}_{4}$ at a scan rate of $10 \mathrm{mV}$ s ${ }^{-1}$ at room temperature.
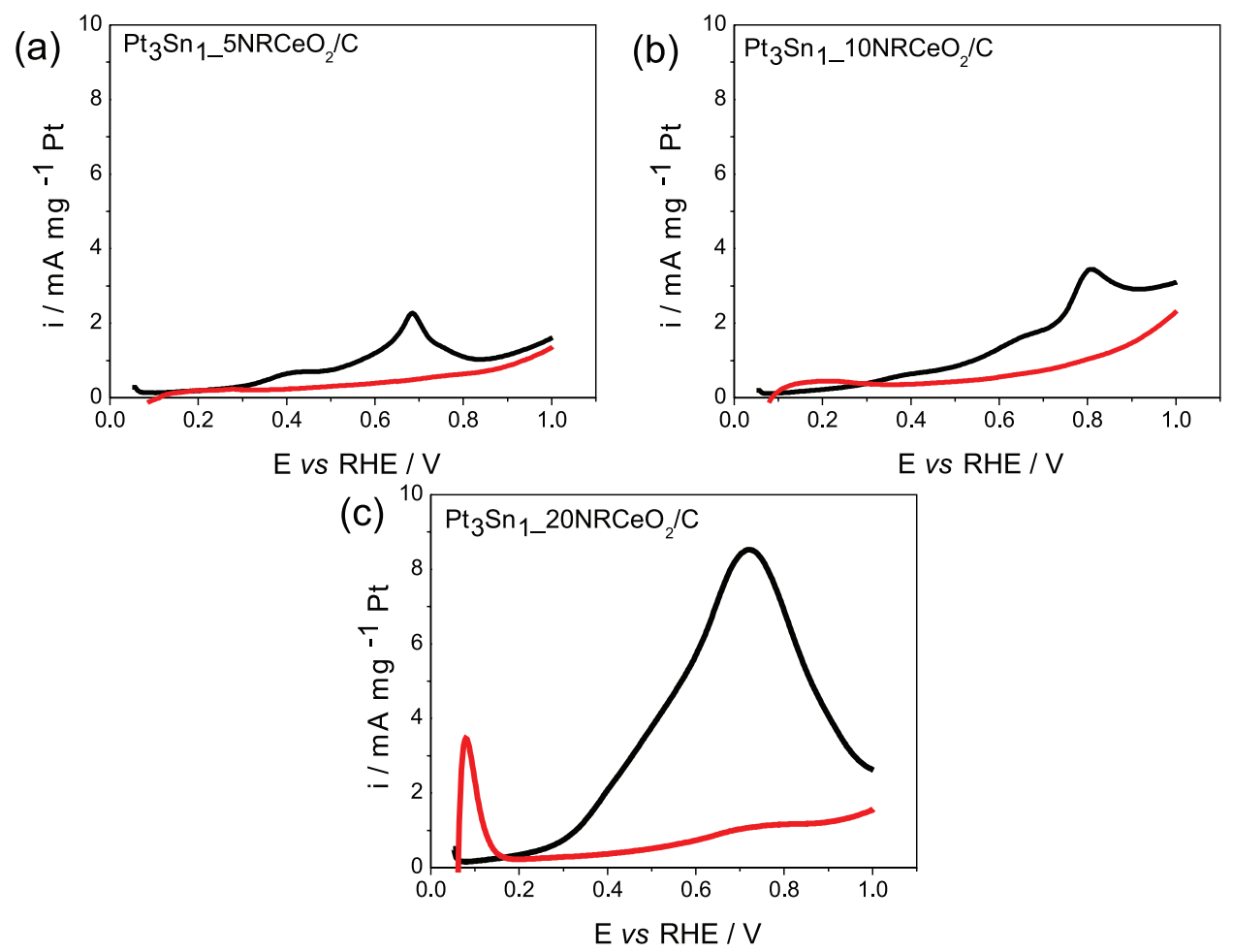

Figure 13. CO stripping curves for (a) $\mathrm{Pt}_{3} \mathrm{Sn}_{1} 5 \% \mathrm{NRCeO}_{2} / \mathrm{C}$; (b) $\mathrm{Pt}_{3} \mathrm{Sn}_{1-} 10 \% \mathrm{NRCeO}_{2} / \mathrm{C}$ and (c) $\mathrm{Pt}_{3} \mathrm{Sn}_{1} \_20 \% \mathrm{NRCeO}_{2} / \mathrm{C}$ electrocatalysts in 0.5 mol L $\mathrm{L}^{-1}$ $\mathrm{H}_{2} \mathrm{SO}_{4}$ at a scan rate of $10 \mathrm{mV} \mathrm{s}^{-1}$ at room temperature.

dissociation of the water is facilitated with the insertion of Sn causing a displacement in the onset oxidation potentials; a fact that is observed in the voltammograms of Figures 12 and 13 .
The $\mathrm{Pt}_{3} \mathrm{Sn}_{1} / \mathrm{C}$ material showed a less positive value for the respective peak to $\mathrm{CO}$ oxidation; however, the $\mathrm{Pt}_{3} \mathrm{Sn}_{1 \_} 20 \mathrm{NRCeO}_{2} / \mathrm{C}$ material displayed a value of $0.72 \mathrm{~V}$, which is considerably less positive than that obtained for 
Table 4. $\mathrm{CO}$ charge, onset oxidation potentials and $\mathrm{CO}$ oxidation potential for the $\mathrm{Pt} / \mathrm{C}, \mathrm{Pt}_{1} \mathrm{Sn}_{1} / \mathrm{C}, \mathrm{Pt}_{2} \mathrm{Sn}_{1} / \mathrm{C}, \mathrm{Pt}_{3} \mathrm{Sn}_{1} / \mathrm{C}, \mathrm{Pt}_{3} \mathrm{Sn}_{1-}$ 5\%NRCeO $/ \mathrm{C}$, $\mathrm{Pt}_{3} \mathrm{Sn}_{1-} 10 \% \mathrm{NRCeO}_{2} / \mathrm{C}$ and $\mathrm{Pt}_{3} \mathrm{Sn}_{1-} 20 \% \mathrm{NRCeO}_{2} / \mathrm{C}$ electrocatalysts

\begin{tabular}{lccc}
\hline Electrocatalyst & CO charge (Q) / coulomb & $\begin{array}{c}\text { Onset oxidation potential / } \\
\text { (V vs. RHE) }\end{array}$ & $\begin{array}{c}\text { Peak potential of CO / } \\
\text { (V vs. RHE) }\end{array}$ \\
\hline $\mathrm{Pt} / \mathrm{C}$ & $2.2 \times 10^{-3}$ & 0.31 & 0.79 \\
$\mathrm{Pt}_{1} \mathrm{Sn}_{1} / \mathrm{C}$ & $1.0 \times 10^{-3}$ & 0.27 & 0.68 \\
$\mathrm{Pt}_{2} \mathrm{Sn}_{1} / \mathrm{C}$ & $1.2 \times 10^{-3}$ & 0.27 & 0.68 \\
$\mathrm{Pt}_{3} \mathrm{Sn}_{1} / \mathrm{C}$ & $1.1 \times 10^{-3}$ & 0.26 & 0.64 \\
$\mathrm{Pt}_{3} \mathrm{Sn}_{1} 5 \% \mathrm{NRCeO}_{2} / \mathrm{C}$ & $5.3 \times 10^{-4}$ & 0.18 & 0.68 \\
$\mathrm{Pt}_{3} \mathrm{Sn}_{1-} 10 \% \mathrm{NRCeO}_{2} / \mathrm{C}$ & $8.5 \times 10^{-4}$ & 0.29 & 0.81 \\
$\mathrm{Pt}_{3} \mathrm{Sn}_{1-} 20 \% \mathrm{NRCeO}_{2} / \mathrm{C}$ & $2.5 \times 10^{-3}$ & 0.16 & 0.72 \\
\hline $\mathrm{RHE}$ & & & \\
\hline
\end{tabular}

RHE: reversible hydrogen electrode.

the $\mathrm{Pt} / \mathrm{C}$ material, which presented value of $0.79 \mathrm{~V}$ for CO oxidation. Asgardi et al. ${ }^{43}$ observed this same redox pair with an anodic peak at approximately $0.75 \mathrm{~V}$ for $\mathrm{CO}$ stripping studies under similar conditions for PtSn type electrocatalysts with different supports and atomic ratios between Pt and Sn.

The oxidation of $\mathrm{CO}_{\text {ads }}$ was used for the calculation of the electrochemically active surface area (ESCA) using equation $3 .^{4,9,38}$

$\mathrm{ESCA}=\frac{\mathrm{Q}}{\operatorname{mass} \mathrm{Pt} \times 420}$

The ESCA is obtained in units of $\mathrm{m}^{2} \mathrm{~g}^{-1} \mathrm{Pt}$; the value of $\mathrm{Q}$ represents the $\mathrm{CO}$ charge in microcoulombs; the platinum mass is expressed in grams, and the value of 420 is expressed in microcoulombs per square centimeter $\left.(\mathrm{mC} \mathrm{cm})^{-2}\right)$ which is a constant that represents a monolayer of adsorbed CO. ${ }^{4,38}$

Based on the $\mathrm{CO}$ charge calculations reported in Table 5, the ESCA for CO oxidation, described in Table 6, was calculated.

The values reported in Table 6 reveal that the $\mathrm{Pt}_{3} \mathrm{Sn}_{1} \_20 \% \mathrm{NRCeO}_{2} / \mathrm{C}$ catalyst is the most promising for oxidation of the intermediate carbon monoxide compound, presenting a chemically active surface area of $79 \mathrm{~m}^{2}$ per gram of platinum, being the most representative among the others. It is important to note that this material presents a $20 \%$ replacement of the metallic load by the cerium oxide NR, which is an effective reduction in the cost arising from the platinum. The activity of the $\mathrm{Pt}_{3} \mathrm{Sn}_{1-} 20 \% \mathrm{NRCeO}_{2} / \mathrm{C}$ catalyst is favorable because the presence of the nanorods facilitated the process of oxidation of $\mathrm{CO}$ to $\mathrm{CO}_{2}$, reducing the catalytic poisoning caused by the interaction of the $\mathrm{CO}$ with the active sites of the Pt.

Thus, the $\mathrm{Pt}_{3} \mathrm{Sn}_{1-2} 20 \% \mathrm{NRCeO}_{2} / \mathrm{C}$ material showed electrocatalytic activity favored by the presence of tin as
Table 5. Onset potential for ethanol oxidation for the electrocatalyst

\begin{tabular}{lc}
\hline Electrocatalyst & Onset potential / ( V vs. RHE) \\
\hline $\mathrm{Pt} / \mathrm{C}$ & 0.51 \\
$\mathrm{Pt}_{1} \mathrm{Sn}_{1} / \mathrm{C}$ & 0.24 \\
$\mathrm{Pt}_{2} \mathrm{Sn}_{1} / \mathrm{C}$ & 0.24 \\
$\mathrm{Pt}_{3} \mathrm{Sn}_{1} / \mathrm{C}$ & 0.15 \\
$\mathrm{Pt}_{3} \mathrm{Sn}_{1 \_} 5 \% \mathrm{NRCeO}_{2} / \mathrm{C}$ & 0.32 \\
$\mathrm{Pt}_{3} \mathrm{Sn}_{1 \_} 10 \% \mathrm{NRCeO}_{2} / \mathrm{C}$ & 0.64 \\
$\mathrm{Pt}_{3} \mathrm{Sn}_{1 \_} 20 \% \mathrm{NRCeO}_{2} / \mathrm{C}$ & 0.18 \\
\hline
\end{tabular}

RHE: reversible hydrogen electrode.

Table 6. Electrochemically active surface area (ESCA)

\begin{tabular}{lc}
\hline Electrocatalyst & ESCA / $\left(\mathrm{m}^{2} \mathrm{~g}^{-1} \mathrm{Pt}\right)$ \\
\hline $\mathrm{Pt} / \mathrm{C}$ & 42 \\
$\mathrm{Pt}_{1} \mathrm{Sn}_{1} / \mathrm{C}$ & 37 \\
$\mathrm{Pt}_{2} \mathrm{Sn}_{1} / \mathrm{C}$ & 35 \\
$\mathrm{Pt}_{3} \mathrm{Sn}_{1} / \mathrm{C}$ & 30 \\
$\mathrm{Pt}_{3} \mathrm{Sn}_{1 \_} 5 \% \mathrm{NRCeO}_{2} / \mathrm{C}$ & 14 \\
$\mathrm{Pt}_{3} \mathrm{Sn}_{1} 10 \% \mathrm{NRCeO}_{2} / \mathrm{C}$ & 24 \\
$\mathrm{Pt}_{3} \mathrm{Sn}_{1 \_} 20 \% \mathrm{NRCeO}_{2} / \mathrm{C}$ & 79 \\
\hline
\end{tabular}

a secondary metal, since it provided oxygenated species for the oxidation of $\mathrm{CO}$ to $\mathrm{CO}_{2}$ through the bifunctional mechanism, releasing the active sites of the base metal $\mathrm{Pt}$ in addition to the contributions in terms of reduction of onset potential for $\mathrm{CO}$ oxidation when compared to the material with higher high-cost metal loads. ${ }^{11}$ The $\mathrm{CeO}_{2} \mathrm{NR}$ present in this electrocatalyst showed a synergistic effect with tin, also favoring the bifunctional mechanism that enables a significant reduction in the use of high-cost metals associated with the metallic platinum. Besides, the presence of $\mathrm{CeO}_{2} \mathrm{NR}$ increase the number of the defects in the material like discussed in our previous work using 
Raman spectra, ${ }^{42}$ in that work only $1 \%$ of $\mathrm{CeO}_{2} \mathrm{NR}$ are present but the ratio between $\mathrm{I}_{\mathrm{D}} / \mathrm{I}_{\mathrm{G}}$ bands of carbon is higher than 1 indicating an increase in the amount of the defects. This behavior suggests not only in our work that there is an electrocatalytical effect, but also that carbon support was also modified by the presence of $4 \%$ of $\mathrm{CeO}_{2} \mathrm{NR}$ (in all load of the catalyst considering $\mathrm{Pt}_{3} \mathrm{Sn}_{1} \_20 \% \mathrm{NRCeO}_{2} / \mathrm{C}$ ). For this reason the effect for the electrocatalysis improvement is related to a synergic effect, not to an individual one.

\section{Conclusions}

In this work, we report that the use of tin in conjunction with cerium-oxide nanorods in platinum-based catalysts enables a significant reduction in the use of high-cost metals by improving the activity for ethanol oxidation.

A $\mathrm{Pt}_{3} \mathrm{Sn}_{1} / \mathrm{C}$ catalyst synthesized with a mass ratio of 75:25 between platinum and tin, respectively, in which the cerium oxide nanorods were applied, presented better results in the electrochemical experiment. $\mathrm{Pt}_{3} \mathrm{Sn}_{1} / \mathrm{C}$ conferred the lowest onset potential $(0.15 \mathrm{~V})$ for catalytic process for ethanol oxidation reactions due to the presence of the secondary metal $(\mathrm{Sn})$, which provides oxygenated species, facilitating the breakdown of the ethanol molecule by release of the active platinum sites and oxidation of intermediate compounds (bifunctional mechanism).

Chronoamperometry experiments indicated that the $\mathrm{Pt}_{3} \mathrm{Sn}_{1} / \mathrm{C}$ catalysts showed the highest mass activity compared with the other materials when rated at a fixed potential of $0.5 \mathrm{~V}$. Among the materials containing the nanorods, the chronoamperometry experiment revealed a greater current density for the $\mathrm{Pt}_{3} \mathrm{Sn}_{1-} 20 \% \mathrm{NRCeO}_{2} / \mathrm{C}$ catalyst at this same potential of $0.5 \mathrm{~V}$. At $0.3 \mathrm{~V}$, the $\mathrm{Pt}_{3} \mathrm{Sn}_{1} / \mathrm{C}$ and $\mathrm{Pt}_{3} \mathrm{Sn}_{1-} 20 \% \mathrm{NRCeO}_{2} / \mathrm{C}$ materials presented currents very close to zero; however, at a fixed potential of $0.4 \mathrm{~V}$, both the aforementioned catalysts showed similar mass activities (2.98 and $2.13 \mathrm{~V}$, respectively).

Among the synthesized catalysts, the $\mathrm{Pt}_{3} \mathrm{Sn}_{1 \_} 20 \% \mathrm{NRCeO}_{2} / \mathrm{C}$ showed more promising activity in the CO-stripping experiment; this catalyst showed a greater value for the electrochemically active surface area $\left(79 \mathrm{~m}^{2} \mathrm{~g}^{-1} \mathrm{Pt}\right)$ and the lowest onset potential $(0.16 \mathrm{~V})$ when compared to the other catalysts due to the presence of oxides that facilitate $\mathrm{CO}$ oxidation to $\mathrm{CO}_{2}$, reducing catalytic poisoning.

It is important to note that the catalyst with ceriumoxide nanorods shows a $20 \%$ reduction in the high-cost metal load compared to the other catalysts; this reduction did not compromise its activity, emphasizing its more favorable behavior in the oxidation of intermediate compounds generated in the oxidation of ethanol, allowing the implementation of cerium-oxide nanorods, in conjunction with platinum and tin, in catalysts, promoting the reduction of costs for the material. The effect observed can be associated with the defects in the structure of the $\mathrm{CeO}_{2}$ nanorods, the electrochemical active surface area, and the $\mathrm{CeO}_{2} \mathrm{NR}$ properties related to the enhancement of the generation of oxy-hydroxide species at lower potentials compared to $\mathrm{PtSn} / \mathrm{C}$ electrocatalysts, increasing the $\mathrm{CO}$ oxidation as measured using stripping experiments. For this reason, it is possible to both use less platinum and obtain behavior close to that found for PtSn/C electrocatalysts for EOR.

\section{Acknowledgments}

The authors thank the Universidade Federal do ABC (UFABC), Multiuser Central Facilities (CEM-UFABC), Instituto de Pesquisas Energéticas e Nucleares (IPENUSP), Fundação de Amparo à Pesquisa do Estado de São Paulo (FAPESP No. 2017/21846-6, 2017/22976-0, 2017/26288-1 and 2017/10118-0) and CNPq (Process No. 429727/2018-6) for their support.

\section{References}

1. Chan, S. H.; Stempien, J. P.; Ding, O. L.; Su, P. C.; Ho, H. K.; Int. J. Hydrogen Energy 2016, 41, 13869.

2. Sharma, S.; Ghoshal, S. K.; Renewable Sustainable Energy Rev. 2015, 43, 1151.

3. Ong, B. C.; Kamarudin, S. K.; Basri, S.; Int. J. Hydrogen Energy 2017, 42, 10142.

4. An, L.; Zhao, T. S.; Li, Y. S.; Renewable Sustainable Energy Rev. 2015, 50, 1462.

5. Dekel, D. R.; J. Power Sources 2018, 375, 158.

6. An, L.; Zhao, T. S.; J. Power Sources 2017, 341, 199.

7. Parreira, L. S.; da Silva, J. C. M.; D’Villa-Silva, M.; Simões, F. C.; Garcia, S.; Gaubeur, I.; Cordeiro, M. A. L.; Leite, E. R.; dos Santos, M. C.; Electrochim. Acta 2013, 96, 243.

8. Beyhan, S.; Léger, J. M.; Kadirgan, F.; Appl. Catal., B 2013, 130-131, 305.

9. Parreira, L. S.; Silva, J. C. M.; Simões, F. R.; Cordeiro, M. A. L.; Sato, R. H.; Leite, E. R.; dos Santos, M. C.; ChemElectroChem 2017, 4, 1950.

10. Higuchi, E.; Miyata, K.; Takase, T.; Inoue, H.; J. Power Sources 2011, 196, 1730.

11. Nandenha, J.; de Souza, R. F. B.; Assumpção, M. H. M. T.; Spinacé, E. V.; Neto, A. O.; Int. J. Electrochem. Sci. 2013, 8, 9171.

12. Liu, Q.; Xu, Y. R.; Wang, A. J.; Feng, J. J.; J. Power Sources 2016, 302, 394.

13. Kim, C.; Lee, H.; Fuel Cells 2013, 13, 889. 
14. Xu, H.; Song, P.; Wang, J.; Gao, F.; Zhang, Y.; Shiraishi, Y.; Du, Y.; ChemCatChem 2018, 10, 2195.

15. Lu, L.; Chen, S.; Thota, S.; Wang, X.; Wang, Y.; Zou, S.; Fan, J.; Zhao, J.; J. Phys. Chem. C 2017, 121, 19796.

16. Spinacé, E. V.; Linardi, M.; Neto, A. O.; Electrochem. Commun. 2005, 7, 365.

17. Das, S.; Kar, S.; Chaudhuri, S.; J. Appl. Phys. 2006, 99, 114303.

18. Ji, Z.; Wang, X.; Zhang, H.; Lin, S.; Meng, H.; Sun, B.; George, S.; Xia, T.; Nel, A. E.; Zink, J. I.; ACS Nano 2012, 6, 5366.

19. Maitarad, P.; Han, J.; Zhang, D.; Shi, L.; Namuangruk, S.; Rungrotmongkol, T.; J. Phys. Chem. C 2014, 118, 9612.

20. Pinheiro, V. S.; Paz, E. C.; Aveiro, L. R.; Parreira, L. S.; Souza, F. M.; Camargo, P. H. C.; Santos, M. C.; Electrochim. Acta 2018, 259, 865.

21. de Souza, R. F. B.; Flausino, A. E. A.; Rascio, D. C.; Oliveira, R. T. S.; Neto, E. T.; Calegaro, M. L.; Santos, M. C.; Appl. Catal., B 2009, 91, 516.

22. Neto, A. O.; Farias, L. A.; Dias, R. R.; Brandalise, M.; Linardi, M.; Spinacé, E. V.; Electrochem. Commun. 2008, 10, 1315.

23. Souza, F. M.; Parreira, L. S.; Hammer, P.; Batista, B. L.; Santos, M. C.; J. Solid State Electrochem. 2018, 22, 1495.

24. Hotza, D.; da Costa, J. C. D.; Int. J. Hydrogen Energy 2008, $33,4915$.

25. Wang, Y.; Chen, K. S.; Mishler, J.; Cho, S. C.; Adroher, X. C.; Appl. Energy 2011, 88, 981.

26. Silva, J. C. M.; de Souza, R. F. B.; Parreira, L. S.; Neto, E. T.; Calegaro, M. L.; Santos, M. C.; Appl. Catal., B 2010, 99, 265.

27. Piasentin, R. M.; de Souza, R. F. B.; Silva, J. C. M.; Spinacé, E. V.; Santos, M. C.; Neto, A. O.; Int. J. Electrochem. Sci. 2013, 8,435 .

28. Jung, D. H.; Bae, S. J.; Kim, S. J.; Nahm, K. S.; Kim, P.; Int. J. Hydrogen Energy 2011, 36, 9115.

29. Spinace, E. V.; do Vale, L. A. I.; Neto, A. O.; Linardi, M.; ECS Trans. 2007, 5, 89.
30. O’Malley, K.; Ordaz, G.; Adams, J.; Randolph, K.; Ahn, C. C.; Stetson, N. T.; J. Alloys Compd. 2015, 645, S419.

31. Steil, M. C.; Fonseca, F. C.; França, Y. V.; Rey, J. F. Q.; Muccillo, E. N. S.; Muccillo, R.; Cerâmica 2002, 48, 146.

32. Martins, T. S.; Hewer, T. L. R.; Freire, R. S.; Quim. Nova 2007, 30, 2001.

33. Nemes, P. I.; Lekka, M.; Fedrizzi, L.; Muresan, L. M.; Surf. Coat. Technol. 2014, 252, 102.

34. Shen, S. Y.; Zhao, T. S.; Wu, Q. X.; Int. J. Hydrogen Energy 2012, 37, 575.

35. Akhairi, M. A. F.; Kamarudin, S. K.; Int. J. Hydrogen Energy 2016, $41,4214$.

36. Higuchi, M.; J. Mater. Chem. A 2015, 3, 290.

37. Li, L.; Liu, H.; Qin, C.; Liang, Z.; Scida, A.; Yue, S.; Tong, X.; Adzic, R. R.; Wong, S. S.; ACS Appl. Nano Mater. 2018, 1, 1104.

38. Chan, K.-Y.; Ding, J.; Ren, J.; Cheng, S.; Tsang, K. Y.; J. Mater. Chem. 2004, 14, 505.

39. Kuznetsov, V. I.; Belyi, A. S.; Yurchenko, E. N.; Smolikov, M. D.; Protasova, M. T.; Zatolokina, E. V.; Duplyakin, V. K.; J. Catal. 1986, 170, 159.

40. Yi, L.; Liu, L.; Wang, X.; Liu, X.; Yi, W.; Wang, X.; J. Power Sources 2013, 224, 6.

41. de Souza, R. F. B.; Silva, J. C. M.; Assumpção, M. H. M. T.; Neto, A. O.; Santos, M. C.; Electrochim. Acta 2014, 117, 292.

42. Pinheiro, V. S.; Paz, E. C.; Aveiro, L. R.; Parreira, L. S.; Souza, F. M.; Camargo, P. H. C.; Santos, M. C.; Electrochim. Acta 2019 , 295, 39.

43. Asgardi, J.; Carlos, J.; Alcaide, F.; Querejeta, A.; Calvillo, L.; Jesús, M.; García, G.; Pastor, E.; Appl. Catal., B 2015, 168-169, 33.

Submitted: December 19, 2018

Published online: April 15, 2019 